\title{
Carbonate system properties and anthropogenic carbon inventory in the Algerian Basin during SOMBA cruise (2014): Acidification estimate
}

\author{
Keraghel Mehdia Asma ${ }^{1, *}$, Louanchi Ferial ${ }^{1}$, Zerrouki Mohamed ${ }^{1}$, Kaci Malik Ait ${ }^{1}$, Aït-Ameur Nadira ${ }^{1}$, \\ Labaste Matthieu ${ }^{2}$, Legoff Hervé ${ }^{2}$, Taillandier Vincent ${ }^{3}$, Harid Romaissa ${ }^{4}$, Mortier Laurent ${ }^{2}$
}

${ }^{1}$ CVRM: Laboratoire de Conservation et de Valorisation des Ressources Marines, Ecole Nationale Supérieure des Sciences de la Mer et de l'Aménagement du Littoral (ENSSMAL), Station de recherche de Sidi Fredj, Algeria

2 LOCEAN: Laboratoire d'Océanographie et du Climat: Expérimentations et Approches Numériques, Unité Mixte de Recherche 7159 CNRS/IRD/Université Pierre et Marie Curie/MNHN, Institut Pierre Simon Laplace, place Jussieu, 75252 Paris, France

${ }^{3}$ LOV: CNRS, Laboratoire d'Océanographie de Villefranche, Sorbonne Universités, Villefranche-surMer, France

${ }^{4}$ ECOSYSMarL: Laboratoire des Écosystèmes Marins et Littoraux, ENSSMAL, Station de recherche de Sidi Fredj, Algeria

* Corresponding author : Mehdia Asma Keraghel, email address : $\underline{\text { ma.keraghel@enssmal.dz }}$

f.louanchi@enssmal.dz ; m.zerrouki@enssmal.dz ; m.ait-kaci@enssmal.dz ; matthieu.labaste@locean-ipsl.upmc.fr ; herve.legoff@locean-ipsl.upmc.fr ; taillandier@obs-vlfr.fr ; r.harid@enssmal.dz; mortier@locean-ipsl.upmc.fr

\begin{abstract}
:
Recent studies have provided a better understanding of carbonate system parameters and their spatial and temporal variability in several areas of the Mediterranean Sea. This study uses a new dataset that covered the entire Algerian Basin during the summer of 2014 (SOMBA cruise) to describe the distribution of carbonate system parameters. The findings show that almost the entire basin was a source of $\mathrm{CO} 2$ to the atmosphere during the studied period. Besides the well-known TrOCA (Tracer combining Oxygen, Carbon and total Alkalinity) approach, the study proposes new parametrization for the standard back calculation method to assess the anthropogenic carbon concentration. The results of both approaches yield similar distributions and concentration ranges $(81 \pm 4.3$ and $69 \pm 5.2 \mu \mathrm{mol} / \mathrm{kg}$, respectively). This study assesses the errors for both approaches and emphasizes the importance of mesoscale and submesoscale structures on anthropogenic carbon sequestration and the distribution of carbonate parameters in the Algerian Basin. It shows that these features enhance basin ventilation and acidification. The first inventory of the anthropogenic carbon trapped by the Algerian Basin is estimated at 0.44$0.53 \pm 0.06 \mathrm{Pg} \mathrm{C}$, based on the new dataset.
\end{abstract}




\section{Highlights}

- The first high resolution spatial coverage of the Algerian Basin allowed a detailed study of the carbonate parameters. A refitted back-calculation method is applied to estimate anthropogenic carbon concentrations. Highlighting the role of the submesoscale processes in the increase of anthropogenic carbon sequestration. The estimated acidification of the Algerian Basin, from the preindustrial era to 2014, range between -0.19 and $-0.1 \mathrm{pH}$ unit. The first estimate of the anthropogenic carbon inventory trapped by the Algerian Basin is at $0.44-0.53 \pm 0.06 \mathrm{Pg} \mathrm{C}$.

Keywords : Algerian Basin, Carbonate system, Anthropogenic carbon inventory, Acidification, Mesoscale activity 


\section{Introduction}

The Mediterranean Sea (MS) plays a relevant role in anthropogenic carbon $\left(\mathrm{C}^{\text {ant }}\right)$ sequestration because it is highly sensitive to global warming and climate change (Álvarez et al., 2014; Touratier et al., 2012). The MS has built up larger $C^{\text {ant }}$ inventories throughout its water column than the global ocean (Lee et al., 2011; Schneider et al., 2010). This is caused by its elevated Total Alkalinities (TA), a Revelle Factor of $\sim 9$ in surface waters, and its active water circulation. Moreover, many authors showed that the MS a source of $\mathrm{CO}_{2}$ to the Atlantic Ocean (e.g., Ait-Ameur and Goyet, 2006; Huertas et a'. 009), whence the growing interest in assessing the sequestered $\mathrm{C}^{\text {ant }}$ into this margina su during the last few decades (Malanotte-Rizzoli et al., 2014).

The scientific community took an interest in the ${ }^{\top}$ no int of sequestered $\mathrm{C}^{\text {ant }}$ in the MS in the early 2000s. The temporal evolution of $C^{\text {.nt }}$ r oncentrations, from the mid-1990 to the mid2000, was studied at the DYFAMED (?vnamique des Flux Atmosphériques en Mediterranée) site using the TrOCA approach (Touia ie and Goyet, 2009). This work was later expanded throughout the MS by Touratier ani Goyet (2011) using the METEOR M51/2 dataset (2001). Schneider et al. (2010) appis a i indirect method to the same dataset to estimate the amount of $\mathrm{C}^{\text {ant }}$ trapped in the $e_{n} t_{-}-$vasin of the MS (TTD Method: Transient Time Distribution). Ait-Ameur and Goyet (2006), Huertas et al. (2009), and Rivaro et al. (2010) also applied the TrOCA approach to estimate the $\mathrm{C}^{\text {ant }}$ concentrations in the Strait of Gibraltar and other locations around the MS. In 2012, Touratier et al. (2012) re-estimated the $C^{\text {ant }}$ concentrations based on the BOUM dataset (Biogéochimie de l'Oligotrophie à l'Ultra-oligotrophie de la Méditerranée) collected in 2008. This study compared two direct approaches, the TrOCA and the MIX - optimum multiparameter MIXing analysis - to estimate the $\mathrm{C}^{\text {ant }}$ accumulation at about $0.8-1.2 \mu \mathrm{mol} . \mathrm{kg}^{-1} \cdot \mathrm{yr}^{-1}$. In 2013, the MedSea dataset (Mediterranean Sea Acidification 
in A Changing Climate) allowed Hassoun et al. (2015a) to record $\mathrm{C}^{\text {ant }}$ concentrations as high as $102 \mu \mathrm{mol} / \mathrm{kg}$ through the TrOCA approach. Such high values indicate the acidification of the MS being between -0.15 and $-0.05 \mathrm{pH}$ units (Hassoun et al., 2015a; Touratier and Goyet, 2011). This places the MS at the top of the most acidified marine ecosystems (Touratier et al, 2012). The $C^{\text {ant }}$ concentrations in the MS were also estimated using either a high-resolution regional model (Palmiéri et al., 2015) or the temporal variations of the stable carbon isotope ratio of dissolved inorganic carbon in the Levantine Basin (Sisma-Ventura et al., 2016).

The aforementioned studies highlighted the important role of "it vestern MS in trapping $\mathrm{C}^{\text {ant }}$, particularly, in the Algerian Basin (AB). They promoted a bett $r$ understanding of the basin's role in the regional carbon cycle and $\mathrm{C}^{\text {ant }}$ sequestratior. The $\mathrm{AB}$ 's complex mesoscale features (the Algerian Current, anticyclonic eddies, cyclonic óyres, are essential for spreading the Modified Atlantic Waters (MAW) in the MS a 1 n nudulating the trophic regime of the AB. Nevertheless, the effects of these physical cuctures on the carbonate system and its anthropogenic fraction have not been ctuc:-ad thoroughly (e.g., Moutin and Prieur, 2012). This region has seldom been investigat a hy oceanographic cruises over the past few decades (e.g., the METEOR cruises in Octohe 2001 and April 2011, the BOUM in June 2008, and the MedSea in May 2013). A sitionally, these cruises have not covered important areas of the $\mathrm{AB}$.

This work benefits from a new dataset collected in the summer of 2014 that completely covers the $\mathrm{AB}$. The SOMBA cruise (Système d'Observations à la mer dans le Bassin Algérien) was conducted in the context of MERMEX (Marine Ecosystems' Response in the Mediterranean Experiment Program) that aims at studying the influence of global warming and anthropogenic activities on the marine ecosystems of the MS (Durrieu de Madron et al., 2011). First, we addressed the spatial distribution of carbonate system parameters in the $A B$ by focusing on the east-west and north-south gradients. Second, the $\mathrm{C}^{\text {ant }}$ concentration was 
estimated using the TrOCA approach (Touratier et al., 2007) in addition to a refitted Chen and Millero (1979) method that was parametrized for preindustrial conditions using knowledge on the MS carbonate system acquired over the last two decades. Finally, the $\mathrm{C}^{\text {ant }}$ concentrations obtained using the two methods were discussed, emphasizing the role of mesoscale activity on the distribution of this parameter. A first estimate of the amount of $C^{\text {ant }}$ sequestered by the $A B$ from the preindustrial period to the summer of 2014 was derived from this new dataset.

\section{Material and Methods}

\subsection{SOMBA dataset}

The SOMBA cruise, dedicated to studying the AB, w is c vnducted between August $14^{\text {th }}$ and September $10^{\text {th }}, 2014$ on the French R/V "Téthys II" (Morier et al., 2014). This FrenchAlgerian cruise had four legs, including sambr 'g at 70 hydrological stations along 7 sections

(Fig. 1). At each station, an underwater san., ling system was lowered from the surface to the bottom. The system included a SeaBir. S2E911+ CTD (Conductivity-Temperature-Depth) unit and a carousel of 11 Niskin totic (12 L each). The temperature and practical salinity were measured with a precisic $n \iota^{c} \pm 0.002{ }^{\circ} \mathrm{C}$ and \pm 0.003 , respectively. The data were pretreated through manua' cieck outs and spike removal. The instrumentation errors were corrected by applying the SBE Data Processing software. The sensors' drift was corrected based on the manufacturer's recommendations, in addition to salinity measurements of discrete samples, taken directly from the Niskin bottles, using an autosalinometer. The CTD was also interfaced with a dissolved oxygen sensor (SBE43). Each station was sampled over eleven depth levels. Discrete samples were collected for dissolved oxygen (12 stations), Dissolved Inorganic Carbon/Total Alkalinity (DIC/TA) (22 stations) and nutrients (70 stations). 
Dissolved oxygen sensor responses were calibrated using daily oxygen measurements performed by Winkler potentiometric titrations, based on Longdon (2010)'s modified method. The sensor's calibration coefficients were statistically adjusted by using multiple Winkler water samples and sensor voltages over a wide range of oxygen calculations (SBE, 2010). Thirty-two duplicates were sampled at different depths with an estimated precision of 1.6 $\mu \mathrm{mol} / \mathrm{kg}$. Quality control checks were performed for all the parameters, based on the recommendations of the Global Ocean Ship-based Hydrographic Investigations Program (GoSHIP) (Swift, 2010). Subsequently, the data were flagged using W. rld Ocean Circulation Experiment (WOCE) standards. Only data deemed "good" wu "e selected for this study.

\subsection{Geochemical parameters measurements}

Carbonate system parameters were sampled in $5 \mathrm{i}, \mathrm{m} /$ borosilicate glass vials (222 samples) and poisoned with $100 \mu \mathrm{l}$ of a saturated $r$ erc sric chloride solution $\left(\mathrm{HgCl}_{2}\right)$, based on Dickson et al. (2007)'s recommendations. Subsu ruently, the samples were analyzed for DIC and TA at the SNAPO-CO $\mathrm{CO}_{2}$ Laboratory (Service $\mathrm{v}$ : tional d'Analyses des Paramètres Océaniques du $\mathrm{CO}_{2}$, France) through closed-ce pu entiometric titration, based on the procedure described by Edmond (1970). The non-liis ar east squares procedure described in DOE (1994) was used to determine equivalent $p$ in i Thirteen duplicates were homogeneously sampled over the cruise's time and space scales. Their repeatability was expressed using the short-term standard deviation $-2 \mu \mathrm{mol} / \mathrm{kg}$ and $3.3 \mu \mathrm{mol} / \mathrm{kg}$ for TA and DIC, respectively. The absolute differences $(\mathrm{R})$ of the duplicate measurements did not exceed the Upper Control Limit described by Dickson et al. (2007) — UCL $=3.267 \times \mathrm{R}: 6.5 \mu \mathrm{mol} / \mathrm{kg}$ and $10.7 \mu \mathrm{mo} / \mathrm{kg}$ for TA and DIC, respectively. Temporal drifts of the concentration of the diluted hydrochloric acid solution were corrected using Dickson Certified Reference Materials (CRM) provided by the University of California- San Diego (batch 139: TA=2250.8 $\pm 0.6 \mu \mathrm{mol} / \mathrm{kg}$, DIC=2023.2 \pm 0.7 
$\mu \mathrm{mol} / \mathrm{kg}$ ). Nutrient concentrations were determined by an automatic colorimetric procedure with a Technicon Auto Analyzer (Tréguer and LeCorre, 1975) at the MIO Laboratory (Mediterranean Institute of Oceanography- France). The precision of the nitrite, nitrate, soluble reactive phosphate, and silicic acid measurements was $2 \%, 3-5 \%, 3-5 \%$, and $5 \%$, respectively while the detection limits were $0.03 \mu \mathrm{M}, 0.05 \mu \mathrm{M}, 0.02 \mu \mathrm{M}$, and $0.05 \mu \mathrm{M}$, respectively.

\subsection{Carbonate system parameter calculations}

Carbonate system properties were sampled at 22 stations of the 2JMBA cruise. We computed multiparametric linear regressions for TA and DIC, versu potential temperature $(\theta)$, practical salinity $\left(\mathrm{S}_{\mathrm{P}}\right)$, and Apparent Oxygen Utilization (AOU , extrapolate discrete TA and DIC measurements over the entire basin. Researchers $r_{d V}$, already reported a linear relationship between the TA and $S_{p}$ in the MS (Copir Mr atégut and Bégovic, 2002; Hassoun et al., 2015b). Nevertheless, this correlation L'apends on the region of the MS (e.g., Cossarini et al., 2015) and seems stronger in the $A B, c$ la acterized by fewer sources of TA variability than the eastern MS (the riverine and the Da. danelle inputs). Lee et al. (2006) also showed that temperature can partly explain $\mathrm{T} 4$ variability.

DIC variability depends $\cdots$ both physical and biological processes (e.g., Goyet and Davis, 1997) and was expressed against $\theta, S_{\mathrm{P}}$, and AOU. Several equations were tested for TA and DIC interpolations using the SOMBA cruise data, either by accounting for the entire water column or by dividing the dataset into three layers (surface, intermediate, and deep waters). Regressions for the eastern and western gyres of the $\mathrm{AB}$ were also tested based on Testor et al. (2005)'s findings. Additionally, we evaluated previously published equations for the AB (Gemayel et al., 2015; Hassoun et al., 2015b; Touratier and Goyet, 2009; Touratier and Goyet, 2011). The Root Mean Square Deviation (RMSD) always exceeded $20 \mu \mathrm{mol} / \mathrm{kg}$ for 
the latter equations. The most appropriate equations for the intermediate and deep waters were found to be $( \pm$ RMSD):

$T A=131.005 S_{p}-9.118 \theta-2329.812( \pm 4.6 \mu \mathrm{mol} / \mathrm{kg})$

$D I C=64.812 S_{p}-5.384 \theta+0.483 A O U-120.117( \pm 8.2 \mu \mathrm{mol} / \mathrm{kg})$

These equations offer an acceptable coefficient of determination (0.62 and 0.98 for TA and DIC, respectively), a mean residual value of 0 , and the lowest standard deviation of the residuals $\left(\mathrm{SD}_{\mathrm{R}}\right)$ and $\mathrm{RMSD}\left(4.6 \mu \mathrm{mol} / \mathrm{kg}\right.$ and $8.2 \mu \mathrm{mol} / \mathrm{kg}$ for $\mathrm{T}_{\mathrm{s}}$ and DIC, respectively) for intermediate and deep layers. This is equivalent to an error of $\mathrm{\iota} .15 \%$ and $0.36 \%$ for averaged TA and DIC concentrations, respectively. It is within tw: e the measurement precision (Fig. 2).

TA and DIC data were normalized to the pra $t_{h}, 1$, alinity based on the procedure developed by Friis et al. (2003). The following equ ior, were applied:

$$
\begin{aligned}
& N T A=\frac{T A-T A^{S=0}}{S_{p}} \times S^{r e f}+T A^{S=\wedge} \text { win } T A^{S=0}=-998 \mu \mathrm{mol} / \mathrm{kg} \\
& N D I C=\frac{D I C-D I C}{S_{p}} \times S^{r e^{+}}+L I C^{S=0} \text { with } D I C^{S=0}=-2215 \mu \mathrm{mol} / \mathrm{kg}
\end{aligned}
$$

where $T A^{S=0}$ and $D I I^{S=0}$ an the non-zero freshwater endmembers and $S^{\text {ref }}$ is the reference salinity (38 for the MS)

The $\mathrm{pH}$ on the total proton concentration scale $\left(\mathrm{pH}_{\mathrm{T}}\right)$ and the partial pressure of $\mathrm{CO}_{2}\left(p \mathrm{CO}_{2}{ }^{\mathrm{sw}}\right)$ were calculated using the CO2SYS macro, version 2.1 (Pierrot et al., 2006). The parameters were set to follow the recommendations of Álvarez et al. (2014): equilibrium constants $\mathrm{K}_{1}$ and $\mathrm{K}_{2}$ from Mehrbach et al. (1973), as refitted by Dickson and Millero (1987); the sulphate dissociation constant from Dickson (1990); the total boron-salinity relationship from Uppström (1974). The SOMBA silicate and soluble reactive phosphate concentrations with 
their relevant constants were also used. The air-sea gradient of $p \mathrm{CO}_{2}\left(\Delta p \mathrm{CO}_{2}\right)$, the difference between the oceanic and atmospheric $p \mathrm{CO}_{2}\left(p \mathrm{CO}_{2}{ }^{\mathrm{sw}}\right.$ and $p \mathrm{CO}_{2}{ }^{\text {air }}$, respectively), was calculated using the following equations:

$\Delta p C O_{2}=p C O_{2}^{s w}-p C O_{2}^{a i r}$

$p \mathrm{CO}_{2}^{\text {air }}=x \mathrm{CO}_{2} \times\left(\right.$ patm $\left.-p \mathrm{H}_{2} \mathrm{O}\right)$

where $\mathrm{xCO}_{2}$ is the Atmospheric Carbon Dioxide Dry Air Mole Fraction retrieved from the World Data Centre for Greenhouse Gases ("WDCGG," 2018). ¿..' stations located around the $\mathrm{AB}$ were selected to compute the mean $\mathrm{xCO}_{2}$ for the two perinc ' 1 ,etween 17-31 August and 01-08 September (390 $2.8 \mathrm{ppm}$ and $393 \pm 2.4 \mathrm{ppm}$, resp tiveıy) (Table 1). patm is the atmospheric pressure, obtained from the NCEP/DOE i M.P-II Daily reanalysis (Reanalysis 2) averages gridded at a $2.5^{\circ}$ resolution. The data $\mathrm{f} r \mathrm{ni}$ analysis were provided by the NOAA/OAR/ESRL PSD (Kanamitsu et . ., $\angle 00<, p \mathrm{H}_{2} \mathrm{O}$ is the water vapor pressure calculated according to Weiss and Pris (198U)'s equation, assuming that the air above the air-sea interface is water saturated.

\subsection{Anthropogenic carbon in *entory}

The $\mathrm{AB}$ was divided into a gr $\mathrm{d}$ of eleven boxes of $2^{\circ}$ longitude by $2^{\circ}$ latitude each to compute the inventory ${ }^{f}$ is sequestered $C^{\text {ant }}$. A vertical profile of $C^{\text {ant }}$ concentrations for each box was calculated by averaging the data from layers of varying thicknesses, ranging from $150 \mathrm{~m}$ to the ocean floor, following the MEDAR/MEDATLAS (Mediterranean Data Archaeology and Rescue) vertical grid standard (Equation 7). The sum of all the boxes represents the total $\mathrm{C}^{\text {ant }}$ inventory of the $\mathrm{AB}$. The associated uncertainty was assessed by an error propagation equation.

$C_{\text {box-inv }}^{\text {ant }}(g C)=\left[\sum_{i=150 m}^{\text {bottom }}\left(C_{i}^{\text {ant }} \times d z_{i} \times \rho_{i}\right) \times 12 /\left(z_{\text {bottom }}-150\right)\right] \times V o l_{\text {box }}$ 
where $C_{\text {box-inv }}^{a n t}$ is the anthropogenic carbon inventory for each box in grams of carbon $(\mathrm{g} \mathrm{C})$; $C_{i}^{a n t}$ is the computed anthropogenic carbon concentration $(\mathrm{mol} / \mathrm{kg}) ; \mathrm{dz}$ is the corresponding thickness of the layer $(\mathrm{m}) ; \rho_{\mathrm{i}}$ is water density expressed in $\mathrm{kg} / \mathrm{m}^{3} ; 12$ is the atomic mass of carbon $(\mathrm{g} / \mathrm{mol}) ; \mathrm{Z}_{\text {bottom }}$ is the bottom depth of the profile $(\mathrm{m})$; $\mathrm{Vol}_{\mathrm{box}}$ is the computed volume of the box $\left(\mathrm{m}^{3}\right)$, based on the $\mathrm{AB}$ bathymetry provided by the General Bathymetric Chart of the Oceans (GEBCO, 2019).

\section{Results and Discussion}

\subsection{Anthropogenic carbon and acidification assessmf at}

In this study, we calculated the $C^{\text {ant }}$ concentration usjr g to o different approaches. First, the back-calculation technique proposed by Chen an $\%$ : 1illero (1979). Second, the TrOCA method proposed by Touratier et al. (2007). Th methods were selected for their simplicity, data availibility, and adaptability to the char 'teristics of the MS. They were not applied to the mixed surface layer $(0-150 \mathrm{~m}) \mathrm{b} f \ddot{\mathrm{o}}$. se of its physical and chemical variability (air-sea exchanges and biological process.s).

\subsubsection{The Chen and Mili *o (1979) approach (MCM)}

The measured DIC includt ; a natural (preformed, preindustrial carbon, $\mathrm{C}^{0, \mathrm{PI}}$ ) and an anthropogenic fraction $\left(\mathrm{C}^{\text {ant }}\right)$, in addition to the in-situ DIC generated (or consumed) by biological processes $\left(\mathrm{C}^{\text {bio }}\right)$. Consequently, anthropogenic carbon concentration is calculated as:

$C^{a n t}=D I C-C^{b i o}-C^{0, P I}$

with: $C^{\text {bio }}=0.5 \Delta T A-\left(C / O_{2}+0.5 \mathrm{~N} / \mathrm{O}_{2}\right) \cdot \Delta O_{2}$

$\Delta T A=T A-T A^{0}$ and $\Delta O_{2}=O_{2}^{0}-O_{2}^{m e s}=A O U$ 
where $\mathrm{TA}$ and $\mathrm{TA}^{0}$ correspond to the measured and preformed alkalinity, respectively. $\mathrm{TA}^{0}$ is calculated by applying Equation 11, derived from the SOMBA surface data (0-150 m).

$T A^{0}=93.779 \mathrm{~S}_{p}-0.57 \theta-1004.765( \pm 7.5 \mu \mathrm{mol} / \mathrm{kg})$

$\mathrm{C} / \mathrm{O}_{2}$ and $\mathrm{N} / \mathrm{O}_{2}$ are the molar ratios proposed by Anderson (1995) based on the average composition of planktonic organic matter $\left(\mathrm{C}: \mathrm{N}: \mathrm{P}:-\mathrm{O}_{2}=106: 16: 1:-150\right) ; \mathrm{O}_{2}{ }^{\text {mes }}$ and $\mathrm{O}_{2}{ }^{0}$ are the measured and preformed dissolved oxygen concentrations, respectively; $\Delta \mathrm{O}_{2}$ can be equated to AOU. The preformed oxygen concentration is usually assum ${ }^{2}$ to be equal to the saturation value with respect to the atmosphere. At the DYFAMED site, 20 r zars of observational data reveal that seawater is undersaturated with respect to oxy że ir. winter (Copin-Montégut and Bégovic, 2002 ; Coppola et al., 2018). Therefore, in th is $\mathrm{s}$ ddy, the preformed oxygen is assimilated to a seawater undersaturation of $4 \%$ ilo corresponds to the winter mean observations in the deep-water formation . . . . in the western MS, this area lies in the Gulf of Lion, off the French coast. Seawater oxygen aturation is calculated using the equation of Benson and Krause (1984).

\subsubsection{Preformed, preindust ia: carbon parametrization $\left(\mathbf{C}^{\mathbf{0}, \mathbf{P I}}\right)$}

All water masses in the MS i ${ }^{\text {? }} \mathrm{ve}$ already been contaminated by $\mathrm{C}^{\text {ant }}$ because of their short water renewal time. The Diviormed, preindustrial DIC concentration $\left(\mathrm{C}^{0, \mathrm{PI}}\right)$ can be determined by assuming a preindustrial partial pressure of $\mathrm{CO}_{2}\left(p \mathrm{CO}_{2}\right)$ of $280 \mathrm{ppm}$ and a constant preformed alkalinity $\left(\mathrm{TA}^{0}\right)$ (Equation 11$)$. This simplified parametrization corresponds to the $\mathrm{C}^{*}$ of Gruber et al. (1996). This term also accounts for the air-sea disequilibrium of $\mathrm{CO}_{2}$ when water masses were last in contact with the atmosphere. Several studies in the deep-water formation region show that seawater is undersaturated with respect to $\mathrm{CO}_{2}$ in winter, with a maximum undersaturation of $-80 \mu \mathrm{atm}$ and a mean value between $-30 \mu \mathrm{atm}$ to $-40 \mu \mathrm{atm}$, depending on the investigated time-period. This result is based on the in-situ data at the 
DYFAMED site (Copin-Montégut et al., 2004; Hood and Merlivat, 2001) and on regional model outputs (D’Ortenzio et al., 2008; Taillandier et al., 2012). Thus, computing a preindustrial, preformed DIC from a $280 \mathrm{ppm} p \mathrm{CO}_{2}$ systematically underestimates the $\mathrm{C}^{\text {ant }}$ concentration, since it overestimates the $\mathrm{C}^{0, \mathrm{PI}}$. Therefore, we chose to compute $\mathrm{C}^{0, \mathrm{PI}}$ by considering a $p \mathrm{CO}_{2}$ undersaturation of $-30 \mu \mathrm{atm}$ (water $p \mathrm{CO}_{2}=250 \mu \mathrm{atm}$ ) during winters for the preindustrial era. We will use the acronym MCM for the Modified Chen and Millero (1979) approach.

\subsubsection{Sensitivity tests and uncertainty estimation}

The MCM approach is based on three main assumptions: 1. hir ogical activity remains constant over time; 2 . the MS is at a steady state; $3 . t^{t}=$ an $\cdot$ sea winter disequilibrium in the deep-water formation area has been constant sinc, the preindustrial period. Sensitivity tests have been performed to assess the errors in the elected parametrization used to calculate $\mathrm{C}^{\text {ant }}$ concentrations (systematic errors). We concinted four sets of tests:

- The preformed alkalinity wa. cal alated using two equations: Hassoun et al. (2015b)'s equation for the Liguro-Pru encal surface waters $(0-25 \mathrm{~m})$ derived from the MEDSEA cruise $\left(\mathrm{TA}^{0}=120.72 \mathrm{~S}_{\mathrm{p}}-1282.6\right)$ and Copin-Montégut and Bégovic (2002)’s equation for $\mathrm{s}$. rfaie $\mathrm{v}$ aters at the DYFAMED site $\left(\mathrm{TA}^{0}=93.996 \mathrm{~S}_{\mathrm{p}}-1038.1\right)$.

- We used another set of stoichiometric ratios (Körtzinger et al., 2001) corresponding to the revised Redfield ratios with a corrected carbon coefficient for the anthropogenic $\mathrm{CO}_{2}\left(\mathrm{C}: \mathrm{N}: \mathrm{P}: \mathrm{O}_{2}=123: 17.5: 1:-165\right)$.

- A $2 \%$ undersaturation of seawater was tested instead of $4 \%$ for the preformed oxygen concentrations, considering that the oxygen solubility pump may enhance oxygen concentrations in cold surface waters. 
- Taillandier et al. (2012) showed that the winter air-sea $\Delta p \mathrm{CO}_{2}$ is decreasing $\left(p \mathrm{CO}_{2}{ }^{\text {atm }}\right.$ is rising faster than that of the ocean). Thus, we tested an undersaturation of -20 $\mu$ atm $\left(p \mathrm{CO}_{2}=260 \mu \mathrm{atm}\right)$ for the preindustrial situation.

The random error associated with the estimated $\mathrm{C}^{\text {ant }}$ concentrations was computed through error propagation using the formula described in Gruber et al. (1996), assuming that the errors were independent of each other $\left(\sigma_{\mathrm{O}_{2}}=1.6 \mu \mathrm{mol} / \mathrm{kg}, \sigma_{\mathrm{O}_{2}^{0}}=4.9 \mu \mathrm{mol} / \mathrm{kg}, \sigma_{\mathrm{TA}}=\right.$ $2 \mu \mathrm{mol} / \mathrm{kg}, \sigma_{\mathrm{TA}^{0}}=7.5 \mu \mathrm{mol} / \mathrm{kg}, \sigma_{\mathrm{DIC}}=3.3 \mu \mathrm{mol} / \mathrm{kg}, \sigma_{\mathrm{C}^{0, \mathrm{PI}}}=3 \mu \mathrm{mol} / \mathrm{kg}, \sigma_{\frac{\mathrm{C}}{\mathrm{O}_{2}}}=$ $\left.0.0816, \sigma_{\frac{\mathrm{N}}{\mathrm{O}_{2}}}=0.0097\right)($ Table 2). The RMSD values between the selected and tested

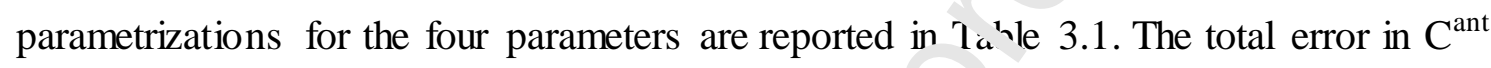
concentrations was $8.3 \mu \mathrm{mol} / \mathrm{kg}$ with a maximum errr $\mathrm{r} \mathrm{c}^{+}$about $12.6 \mu \mathrm{mol} / \mathrm{kg}$ (considering the values of $\sigma_{C^{0, P I}}$ and $\sigma_{T A^{0}}$ from Table 3.1). Sui se ${ }_{1}$ uently, the retained uncertainty is \pm 10 $\mu \mathrm{mol} / \mathrm{kg}$. This is $9.2 \%$ of the computed ( $\mathrm{C}^{\text {ant }}$ values. Table 3.2 shows that stoichiometric parametrization causes the lowest error $n$ the calculation of $C^{\text {ant }}$ concentrations $(2.2$ $\mu \mathrm{mol} / \mathrm{kg}$ ). Preformed oxygen and TA ${ }^{-}$ametrizations generate an uncertainty of the same order of magnitude ( $3 \mu \mathrm{mol} / \mathrm{kg}$ ), whereas the estimate of $\mathrm{C}^{0, \mathrm{PI}}$ introduces an error of up to 9.4 $\mu \mathrm{mol} / \mathrm{kg}$. Nevertheless, the st. ${ }^{\circ}$.ivity tests' results illustrate that systematic errors in estimating $\mathrm{C}^{\text {ant }}$ concentrations through the MCM approach are acceptable and lie within the estimated random error of $10 \mu \mathrm{mol} / \mathrm{kg}$.

\subsubsection{The TrOCA approach}

The TrOCA is a semi-conservative-tracer model developed by Touratier and Goyet (2004). The model was later improved to better estimate the preindustrial term $\operatorname{TrOCA}^{0}$ (Touratier et al., 2007), and used by the authors, in combination with three tracers $\left(\Delta^{14} \mathrm{C}, \mathrm{CFC}-11\right.$, and $\left.{ }^{3} \mathrm{H}\right)$, to identify old oceanic water masses that are unaffected by the anthropogenic carbon invasion 
in the global ocean. The $\operatorname{TrOCA}^{0}$ was computed as a function of two measurable parameters (TA and $\theta$ ). This approach assumes constant stoichiometric ratios, TA, and oxygen concentrations $\left(\mathrm{O}_{2}\right)$. The anthropogenic carbon concentration is calculated using the following equation:

$C_{A n t}^{\operatorname{TrOCA}}=\frac{O_{2}+1,279\left[D I C-\frac{1}{2} T A\right]-\exp \left(7.511-\left(1.087 \times 10^{-2}\right) \theta-\frac{7.81 \times 10^{5}}{T A^{2}}\right)}{1.279}$

The estimated uncertainty for this method is $\pm 9.8 \mu \mathrm{mol} / \mathrm{kg}$ ( $8.5 \%$ of the $\mathrm{C}^{\text {ant }}$ maximum value), using the error propagation equation described by Touratier et al. (2v07).

\subsubsection{Acidification assessment}

The change in the AB's pH from the preindustrial pe iod ? $2014(\Delta \mathrm{pH})$ was calculated using the following equation:

$\Delta p H=p H_{2014}-p H_{\text {preind }}$

where $\mathrm{pH}_{2014}$ is the computed total $\mathrm{F} \mathrm{H}$ a cribed in section (1.3); $\mathrm{pH}_{\mathrm{preind}}$ is the $\mathrm{pH}_{\mathrm{T}}$ of preindustrial era calculated usin , he preindustrial TA (assuming that TA remains constant over time) and the preindustrial $\mathrm{DlC}\left(\mathrm{DIC}_{\text {preind }}\right)$. The latter was estimated by subtracting the computed anthropogenic fracion from the measured DIC:

$D I C_{\text {preind }}=D I C-C^{a m}$

\subsection{The distribution of carbonate system properties}

\subsubsection{Physical settings}

A hydrological study was conducted before studying the distribution of the carbonate system parameters. It used $\theta / \mathrm{S}_{\mathrm{p}}$ diagrams and the vertical distribution of practical salinity (Fig. 3). Consequently, the basin was separated into three layers. First, the surface layer $(0-150 \mathrm{~m})$, 
characterized by Atlantic Waters (AW) that penetrate the $\mathrm{AB}$ from the Almeria-Oran front, with an Atlantic salinity signature of 36.7. Fig. 1 reveals active mesoscale activity during the SOMBA cruise, characterized by a significant anticyclonic eddy with a Sea Level Anomaly (SLA) of about $0.35 \mathrm{~m}$ centered in the eastern part of the basin at $38.2^{\circ} \mathrm{N} / 5.8^{\circ} \mathrm{E}$. The Algerian Current shows these baroclinic instabilities throughout its eastward progression (Millot and Taupier-Letage, 2005).

Second, the intermediate layer $(150-800 \mathrm{~m})$, mainly marked by the Levantine Intermediate Waters (LIWs) that penetrate the $\mathrm{AB}$ through the Sardinian $\mathrm{C}^{\mathbf{l}}$ ads $\bullet l$, with temperatures between $13.6{ }^{\circ} \mathrm{C}$ and $14.17{ }^{\circ} \mathrm{C}$ and salinities between 38.5 and 38.75. The LIWs are characterized by their minimum oxygen concentration $\quad 0 j-170 \mu \mathrm{mol} / \mathrm{kg}$ ) and high salinities. They flow northward along the western Sa dinla.i coasts to begin their cyclonic path in the western MS, as described in Millot ana ₹aupier Letage (2005). Fig. 3b and Fig. 3d illustrate the separation between the intern $n_{\AA}$ iate waters of the eastern $\left(\sim 4{ }^{\circ} \mathrm{E}-10^{\circ} \mathrm{E}\right)$ and the western $\left(\sim 1^{\circ} \mathrm{W}-4{ }^{\circ} \mathrm{E}\right)$ parts of the basin, : separation that seems to be related to the AB's two cyclonic gyres mentioned by Test or al. (2005). The eastern part of the basin is characterized by a thick layer of younger, warı ${ }^{\circ}$, and saltier waters, while the western part is characterized by older LIWs that have r „ n ıाxed with surrounding waters (Hainbucher et al., 2014). The entrainment of less salty, ub-surface waters and portions of LIWs being torn apart at the center of the basin substantiate the influence of the anticyclonic eddy observed at $6{ }^{\circ} \mathrm{E}$, an observation that corroborates Moutin and Prieur (2012) and Millot and Taupier-Letage (2005)'s findings.

Third, the deep layer (800 m-bottom) is represented by homogeneous Western Mediterranean Deep Waters (WMDWs) with a salinity of 38.48 and a temperature of $12.9{ }^{\circ} \mathrm{C}$, in agreement with earlier observations (e.g., Béthoux et al., 2002; Schroeder et al., 2010). The bottom of the basin is almost entirely covered by more oxygenated, newly formed WMDWs (WMDWn, 
Fig. 3c), characterized by slightly higher salinities and temperatures $\left(38.49\right.$ and $12.91{ }^{\circ} \mathrm{C}$, respectively) than the usual WMDWs. These waters are probably the result of the Western Mediterranean Transient (WMT) described by Schroeder et al. (2008).

\subsubsection{Surface waters $(\mathbf{0}-150 \mathrm{~m})$}

Surface TA and DIC concentrations range between 2400 and $2600 \mu \mathrm{mol} / \mathrm{kg}$ and between 2075 and $2334 \mu \mathrm{mol} / \mathrm{kg}$, respectively. Their mean values are $2517 \pm 46 \mu \mathrm{mol} / \mathrm{kg}$ and $2227 \pm 55$ $\mu \mathrm{mol} / \mathrm{kg}$, respectively (Fig. 4). According to Gemayel et al. (20is), summer conditions favor high TA and DIC concentrations in the AB due to the coastr.. "u rellings driven by summer wind regimes (Bakun and Agostini, 2001). Surface $\mathrm{pH}_{\mathrm{T}}$ ? lues range between 7.97 and 8.17

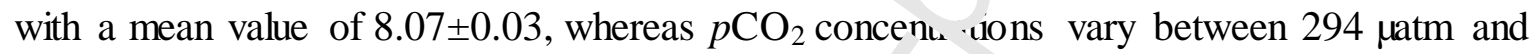
$502 \mu \mathrm{atm}$ with a mean value of $400 \pm 35 \mu \mathrm{atm}$, as $r$ os rved by Copin-Montégut and Bégovic (2002) and Rivaro et al. (2010).

Surface AW flowing eastward from Gib ? ltar in the southern part of the AB have a low TA and DIC signature (Fig. 5a and 5c', Th: waters' increasing salinity causes the increasing eastward and northward gradiem of the inflowing waters (Fig. 5h) that gain Mediterranean characteristics along their rvion path $\left(S_{\mathrm{p}}=36.7\right.$ to 38.5$)$. According to Millero et al. (1998), salinity contributes to $8 \mathrm{\%} /$ of TA variability in surface waters in major ocean basins (Atlantic, Pacific, and Indian Oceans). Cossarini et al. (2015) observed similar distributions of TA in the MS and attributed the north-south gradient to terrestrial inputs. Several researchers noticed similar trends for the DIC distribution using different approaches (e.g., Álvarez et al., 2014; Gemayel et al., 2015; Hassoun et al., 2015b; Schneider et al., 2010). Although our data clearly show that salinity controls the surface TA and DIC variability, the normalized values provide insights about the biogeochemical drivers for these distributions. For instance, the western part of the basin hosts the maximum normalized alkalinities (Fig. 5b), corresponding with 
oxygen oversaturation (Fig. $5 \mathrm{~g}$ ) and $\mathrm{CO}_{2}$ undersaturation of the seawater (Fig. 5f). The latter may imply that the slight increase in TA is associated with photosynthetic activity. Moreover, the NDIC distribution presents a decreasing northward gradient. This suggests that the Algerian Current, and thereby the Atlantic waters, are a source of DIC to the MS (Huertas et al., 2009).

Inflowing $\mathrm{AW}$ have high $\mathrm{pH}$ values (Fig. 5e), likely associated with $\mathrm{CO}_{2}$ consumption through photosynthesis. This makes the southwestern part of the $\mathrm{AB}$ a $\mathrm{CO}_{2}$ sink in late summer. The surface dissolved oxygen and $p \mathrm{CO}_{2}$ values are $\mathrm{s}^{+}{ }_{\star} \mathrm{u}_{1}$. rly correlated $(\mathrm{R}=0.93)$, as also reported by Rivaro et al. (2010). Meanwhile, the more olig trophic MAWs exhibit lower $\mathrm{pH}$ values and are a source of $\mathrm{CO}_{2}$ to the atmosphere $\mathrm{su} \cdot \mathrm{h}$ ost of the basin $\left(\Delta p \mathrm{CO}_{2}=+75 \pm 29\right.$ $\mu$ atm) (Fig. 5f). This is probably caused by the high urfac temperatures $\left(20-27^{\circ} \mathrm{C}\right)$ in summer (high correlation between $p \mathrm{CO}_{2}$ and $\backsim$ rfau temperatures $-\mathrm{R}=0.84$ ), in agreement with the findings of Bégovic and Copin-N- tégut (2002), D’Ortenzio et al. (2008), and Louanchi et al. (2009). The increasing ea 'ward $p \mathrm{CO}_{2}$ gradient was also observed by several researchers in response to the incr $\dot{\mathrm{a}} \mathrm{s}^{`} \mathrm{a}$ ГA and DIC concentrations (e.g., D’Ortenzio et al., 2008; Gemayel et al., 2015; Pivan' et al., 2010; Taillandier et al., 2012). These authors mainly associate $p \mathrm{CO}_{2}$ va in' 'uicy with physical processes (water mixing, air-sea exchange, salinity and temperature) . nd, to a lesser extent, primary production.

\subsubsection{Intermediate and deep waters $(150 \mathrm{~m}$-bottom)}

The TA and DIC concentrations increase with depth and range from 2484 to $2620 \mu \mathrm{mol} / \mathrm{kg}$ and from 2229 to $2357 \mu \mathrm{mol} / \mathrm{kg}$, respectively (Fig. 4), as corroborated by many studies (Álvarez et al., 2014; Hassoun et al., 2015b; Touratier et al., 2012). The spatial distribution of TA and DIC is related to water mass distributions: maximum TA and DIC concentrations are observed in the older and saltier core of the LIWs at around $450 \mathrm{~m}$ (Fig. 6a and Fig. 6c); the 
WMDWs exhibit lower TA and DIC concentrations because they are younger and better oxygenated by deep-water formation processes. The NTA and NDIC distributions do not provide more insights about their variability, except a few anomalies around $6^{\circ} \mathrm{E}$ that may be associated with organic matter remineralization in a mesoscale structure (Fig. 6b and 6d). Such anomalies (higher DIC and lower TA concentrations) were also reported during the BOUM cruise by Touratier et al. (2012). According to Hassoun et al. (2015b), the MS' active overturning circulation enriches deep waters with labile carbon that promotes significant increases in DIC concentration through remineralization. Morenve, convection and advection of dense waters is a more important sink for organic carbo ${ }^{n}$ u. $n$ the sedimentation of particulate matter from the upper layers of the $\mathrm{MS}$ ( $\mathrm{La} \mathrm{Fe}_{1}{ }^{1}$ ' et al., 2003).

Fig. 7 shows the latitudinal and longitudinal mean cc ncenıations of DIC and TA for nonnormalized and normalized data. The results $a^{2} \geq$ pıssented for three depth layers (surface, intermediate, and deep). The surface longl : inal and latitudinal distributions illustrate important fluctuations (through the error : ars) and confirm previous observationsdecreasing gradients eastward for $\mathrm{o}^{\text {th }}$ salinity-normalized parameters (NTA, NDIC) (Fig. 7c and Fig. 7d) and a distinct northw ard decreasing gradient for the NDIC (Fig. 7h). These gradients persist for NDIF : lie intermediate layer due to higher organic matter remineralization in older aters. However, the NTA distribution does not show a significant gradient because biological processes do not impact it much. The non-normalized TA and DIC distributions display an eastward gradient in the intermediate and deep waters. This finding contrasts with Lovato and Vichi (2015) and Cossarini et al. (2015), who reported that the eastward gradient of TA and DIC disappears at a depth of $250 \mathrm{~m}$. Deep waters present only small variations with eastward trends within the uncertainty range for both the normalized and non-normalized data. 


\subsection{Anthropogenic carbon}

\subsubsection{Anthropogenic carbon distribution}

Fig. 8 shows the $\mathrm{C}^{\text {ant }}$ concentration estimates from the two approaches. The concentrations are different but display similar spatial distributions. Generally, they reach the highest values in the upper layer $(150-250 \mathrm{~m})$ that is in direct contact with the enriched surface waters (TrOCA:70-115 $\mu \mathrm{mol} / \mathrm{kg}$; MCM: 59-109 $\mu \mathrm{mol} / \mathrm{kg}$ ). The inflow of old LIWs to the western MS basin in the intermediate layer $(400-1000 \mathrm{~m})$ is characterized hy the lowest $\mathrm{C}^{\text {ant }}$ concentrations (TrOCA: 61-99 $\mu \mathrm{mol} / \mathrm{kg}$; MCM: 50-91 $\mu \mathrm{m}^{r^{1 / 2}}$ z). These concentrations increase in deep waters that are continuously renewed by teep-water formation processes in the Gulf of Lion (TrOCA: 69-100 $\mu \mathrm{mol} / \mathrm{kg}$; MCM: 56- ? $\mu \mathrm{mol} / \mathrm{kg}$ ). Recently, Touratier et al. (2016) provided additional insights about the $\mathrm{r}_{\mathrm{r}}$ pr rtant role of deep-water formation (convection, cascading) on $\mathrm{C}^{\text {ant }}$ sequestr? on in the western MS.

The observed values, similar to those or Yassoun et al. (2015a)'s for the MS in 2013, are higher than earlier estimates (Tour ${ }^{\text {ier }}$ and Goyet, 2011; Touratier et al., 2012). This increasing trend can be explaine ' by the increasing concentrations of atmospheric and surface water $\mathrm{CO}_{2}$, which were confir. $\simeq \mathfrak{d}$ by Marcellin Yao et al. (2016). The intense deep-water convection and cascading recorded in the western MS between 2005 and 2013 (Houpert, 2013; Puig et al., 2013; Schroeder et al., 2008) could have influenced $C^{\text {ant }}$ concentrations in the $\mathrm{AB}$ during the SOMBA cruise. The inflowing Atlantic waters may also be a potential source of $C^{\text {ant }}$ in the $A B$ (Huertas et al., 2009).

The vertical distribution of AOU (Fig. 8c) shows that the mesoscale structures observed during the SOMBA cruise are characterized by less oxygenated waters and lower $\mathrm{C}^{\text {ant }}$ concentrations. This is probably caused by anticyclonic eddies that trap older intermediate waters and entrain them to depth. According to Moutin and Prieur (2012), these structures 
function as closed systems and their vortex barrier prevents large-scale mixing, water advection, and renewal through deep-water formation. Nevertheless, an anomaly with high $\mathrm{C}^{\text {ant }}$ concentrations can be observed near the anticyclonic eddy at $6^{\circ} \mathrm{E}$. It was associated with high DIC and low TA concentrations, while dissolved oxygen concentrations were not significantly anomalous. This could be explained by the entrainment of newly formed waters from their formation area (Gulf of Lion) to the $\mathrm{AB}$ by anticyclonic Submesoscale Coherent Vortices (SCV). In fact, Testor and Gascard (2003) observed such physical structures in the $\mathrm{AB}$ and demonstrated that SCVs can advect newly formed WMI) v' over long distances from their source. Their rotation generates transport barriers that us stically reduce lateral exchange between the core and surrounding waters. This improves :air efficiency at transporting physical and biogeochemical tracers from their origin (L 'sse et al., 2016). These SCVs can also strongly interact with eddies (Testor and $\mathrm{Ca} \cdot \mathrm{ar}$, , 2003), which could be the case for the eddy observed at $6^{\circ} \mathrm{E}$ during the $\mathrm{SOMB} \cdot \mathrm{c}^{c}$ dise. The newly formed and advected waters may be enriched with labile organic carbon s'at consumes the replenished oxygen through remineralization during their transnort. This may explain the lack of a positive dissolved oxygen anomaly. Kessouri et a. (26:8) showed that the total organic carbon export to deep waters in the MS' deep-conv -tir, n area is eight times higher than in the stratified area.

\subsubsection{Comparing the st lected approaches}

The MCM method yields lower $\mathrm{C}^{\text {ant }}$ concentrations than the TrOCA approach, but within the range of the $\mathrm{C}^{\text {ant }}$ uncertainty $(\sim 10 \mu \mathrm{mol} / \mathrm{kg})$ (Table 4$)$. In the last two decades, the TrOCA approach has proven its efficiency and has been accepted as a reliable method for $\mathrm{C}^{\text {ant }}$ assessment in the global ocean (Álvarez et al., 2009; Lo Monaco et al., 2005; VázquezRodríguez et al., 2009) and in the MS (Rivaro et al., 2010; Touratier et al., 2016; Touratier and Goyet, 2009). Nevertheless, some authors suggest that the TrOCA approach might 
overestimate $C^{\text {ant }}$ concentrations (Flecha et al., 2012; Huertas et al., 2009). Recently, Sabine and Tanhua (2010) reviewed the $\mathrm{C}^{\text {ant }}$ assessment methods and questioned the $\operatorname{TrOCA}^{0}$ parametrization and its definition of the preformed values. One may ask: Is the global oceanbased parametrization of the $\operatorname{TrOCA}^{0}$ applicable to the MS? Do the MS waters (high salinity and alkalinity concentrations) have the same preindustrial properties as the global ocean? Yool et al. (2010) showed that the TrOCA approach leads to a factor of two error on the global inventory when including marginal seas. Nevertheless, our results show a strong correlation between the TrOCA and the MCM approaches, if the laiter used Mediterranean parametrizations. This suggests that, based on our results a ı i ensitivity tests, the TrOCA approach is a good proxy for $\mathrm{C}^{\text {ant }}$ assessment in the Wecten $n$ MS. The first source of error in the $\mathrm{C}^{\text {ant }}$ estimates using the MCM approach is the ass $\mathrm{ss}_{2}$ nent of $\mathrm{CO}_{2}$ air-sea disequilibrium. This could lead to a $10 \mu \mathrm{mol} / \mathrm{kg}$ uncertainty (Tht! 2.2), in agreement with Friis (2006)'s results. In this context, winter undersatur ${ }^{+}{ }^{+} 0$, of the western MS probably increased with the increase in atmospheric $p \mathrm{CO}_{2}$ (Tailland ^r et al., 2012). Nevertheless, a recent study by Touratier et al. (2016) shows that dirit? the deep-water convection event in the winter of 2011, the sea-surface waters ac $>d$ as a source of $\mathrm{CO}_{2}$ to the atmosphere, whereas under stratified conditions, they acu $\mathrm{d}$ is a $\mathrm{CO}_{2}$ sink. Morales-Pineda et al. (2014) also reported an important variability or a-surface $p \mathrm{CO}_{2}$ on daily, biweekly, and seasonal scales. These studies, among others, emphasize the complexity and the difficulty of hindcasting the preformed, preindustrial DIC of the MS, implying that a more precise estimate of the real airsea $p \mathrm{CO}_{2}$ disequilibrium is essential to better assess $\mathrm{C}^{\text {ant }}$ concentrations.

Applying the MCM and the TrOCA approaches assumes a constant TA. Nevertheless, recent studies (Cossarini et al, 2015; Gemayel et al., 2015) have found a significant seasonal cycle of the surface TA, mainly driven by physical processes (seasonal cycle of evaporation and vertical mixing): variations reach 30 to $50 \mu \mathrm{mo} / \mathrm{kg}$ in the $\mathrm{AB}$. These observations emphasize 
the need to use linear regressions, deduced from winter conditions in the Gulf of Lion for deep waters and from the Levantine Basin for intermediate waters. Finally, back-calculation techniques, including TrOCA, require that the MS be in steady state. However, this is not the case, as demonstrated by Schroeder et al. (2008) and Hassoun et al. (2015b). The error associated with this assumption is particularly hard to assess using simple back-calculation techniques. Nevertheless, Touratier et al. (2012) obtained results similar to those of the TrOCA approach by applying the MIX approach that accounts for the contribution of various water masses in the MS.

\subsubsection{Anthropogenic carbon inventory}

The estimated metrics and $\mathrm{C}^{\text {ant }}$ inventory for each box a presented in Table 5. According to our results, the $\mathrm{AB}$ sequestered between $0.44 \pm 0 . \vee, \mathrm{F}_{5} \mathrm{C}(\mathrm{MCM})$ and $0.53 \pm 0.06 \mathrm{Pg} \mathrm{C}$ (TrOCA) of $\mathrm{C}^{\text {ant }}$ from the preindustrial $\mathrm{e}^{\mathrm{d}} \mathrm{t}$ to the summer of 2014. The magnitude of the estimated $\mathrm{C}^{\text {ant }}$ inventories is explained hy the intrinsic characteristics of the western MS (high alkalinity, short water renewal times, ict ve mesoscale structures, etc.) and the increase in atmospheric $p \mathrm{CO}_{2}$. Palmiéri et .1. (2015) proposed that the high TA concentrations of the MS enhance its $C^{\text {ant }}$ inventory $b, 10 \%$ compared to the global ocean. Merlivat et al. (2018) indicated that the accur. "Han + DIC during the last 20 years represents almost $30 \%$ of the total inventory of $\mathrm{C}^{\text {ant }}$ in the MS and that external factors, such as Atlantic inputs, also play an important role in $C^{\text {ant }}$ sequestration by the MS. According to Palmiéri et al. (2015), air-sea exchanges alone could explain $75 \%$ of the inventory.

The total inventory of $\mathrm{C}^{\text {ant }}$ in the MS was estimated at $1.7 \pm 0.4 \mathrm{Pg} \mathrm{C}$ by Schneider et al. (2010) and $1 \mathrm{Pg} \mathrm{C}$ by Palmiéri et al. (2015) for 2001. These two inventories were obtained by different techniques (tracer studies and high resolution model, respectively) and for different spatial and temporal scales. It is thus difficult to compare their results with those of this study. 
Nevertheless, as Table 6 illustrates, the estimated $C^{\text {ant }}$ inventory of the $A B$ is within the range of those reported in many other marginal seas in North Pacific (Chen et al., 2004) and Atlantic (Jutterström et al., 2008; Olsen et al., 2010) Oceans. The AB is characterized by higher average excess $\mathrm{CO}_{2}$ per unit area $\left(1482-1790 \mathrm{~g} \mathrm{C}^{-2} \mathrm{~m}^{-2}\right.$ than other marginal seas and oceans because of its intrinsic properties (like low Revelle Factor): e.g., $400 \mathrm{~g} \mathrm{C} . \mathrm{m}^{-2}$ for the Japan Sea (Park et al, 2006), $800 \mathrm{~g} \mathrm{C.m}{ }^{-2}$ for the Sulu Sea, and $330 \mathrm{~g} \mathrm{C} . \mathrm{m}^{-2}$ for the Global Ocean (Chen et al., 2006a).

Fig. 9 shows the horizontal distribution of the $C^{\text {ant }}$ inventory ir un $\mathrm{AB}$ using the two selected approaches in this study (TrOCA and MCM). The lowest : eque stered amounts (9-22 Tg C) are observed in the Sardinian Channel and near Ibiza 'sta. 'a, while the highest correspond with the boxes that have the largest volumes (maxim.m n. box 10 with $74-89 \mathrm{Tg} \mathrm{C}$ ). These results are consistent with Palmiéri et al. (2015)'s vuservation of an important correlation with bathymetry. The highest concentrations or ${ }^{r}$ ant per unit volume are observed in the southern and central parts of the $\mathrm{AB}\left(0.82\right.$ g.m $\mathrm{m}^{-3}$ ( $\left.{ }^{\mathrm{r}} \mathrm{CM}\right)-0.99 \mathrm{~g} \cdot \mathrm{m}^{-3}$ (TrOCA)) (Table 5). The inventory maxima encountered at these long $\iota^{\prime}{ }^{\prime}$ es possibly reflect the active anticyclonic activity in the area. According to Pessini et al. ( 018), the southern part of the basin hosts longer-lived eddies that form and term in ${ }^{\circ}$, vetween $4.5^{\circ} \mathrm{E}$ and $6.5^{\circ} \mathrm{E}$.

\subsection{Acidification est - ates and $\mathrm{CaCO}_{3}$ saturation}

The difference in $\mathrm{pH}$ from the preindustrial era to summer 2014 confirms the high acidification of the $\mathrm{AB}$, with $\Delta \mathrm{pH}$ values ranging from -0.19 to $-0.1 \mathrm{pH}$ unit and a mean value of $-0.12 \pm 0.008 \mathrm{pH}$ unit $\left(\sim-0.0005 \mathrm{pH}\right.$ unit. $\left.\mathrm{yr}^{-1}\right)$ (Table 7). The two approaches used to estimate $\mathrm{C}^{\text {ant }}$ concentrations yield a similar $\mathrm{pH}$ decrease with a mean difference of about 0.01 $\mathrm{pH}$ units - almost within the range of the corresponding standard deviations. According to Marcellin Yao et al. (2016), the increasing atmospheric $\mathrm{CO}_{2}$ accounts for $70 \%$ of the decrease 
in surface $\mathrm{pH}$ at the deep-water formation site while the remaining $30 \%$ is caused by increasing seawater temperatures. Fig. 10 illus trates the distribution of $\Delta \mathrm{pH}$ along the eastwest section of the SOMBA cruise, which is strongly correlated with the $\mathrm{C}^{\text {ant }}$ distribution. The oldest water masses (LIWs) are characterized by the lowest acidification, while the newest are enriched with $\mathrm{C}^{\text {ant }}$ and are the most acidified waters. The anticyclonic eddy at $6^{\circ} \mathrm{E}$ has an acidification of about $-0.13(\mathrm{MCM})$ to $-0.16 \mathrm{pH}$ unit (TrOCA), probably caused by the submesoscale activity mentioned earlier. It is difficult to conclude on the evolution of the acidification based on a comparison of our results with the literatırc (Hassoun et al., 2015a; Touratier et al., 2012; Touratier and Goyet, 2011) (Table 7\%. . The previous acidification estimates considered the entire MS, while this study foriss solely on the $\mathrm{AB}$, which is more acidified than the MS' eastern basin (e.g., Hassoun et aı, 2015a; Touratier and Goyet, 2011).

The saturation states of waters with respect to akcic $\left(\Omega_{\mathrm{ca}}\right)$ and aragonite $\left(\Omega_{\mathrm{ar}}\right)$ are defined by: $\Omega_{c a(a r)}=\frac{\left[\mathrm{Ca}^{2+}\right] \times\left[\mathrm{CO}_{3}^{2-}\right]}{K_{c a(a r)}^{*}}$

where $\mathrm{K}^{*}$ is the stoichiometric $\mathrm{sol}^{-1} \cdot{ }^{*} \mathrm{it}$, product and $\left[\mathrm{Ca}^{2+}\right]$ and $\left[\mathrm{CO}_{3}{ }^{2-}\right]$ are the total calcium and carbonate ion concentrations, respectively.

Variations of the calcite nd ragonite saturation states $\left(\Delta \Omega_{\mathrm{ca}}\right.$ and $\Delta \Omega_{\mathrm{ar}}$, respectively) were calculated by subtracting I e calculated values for the summer of 2014 from the preindustrial values. The mean values of $\Delta \Omega_{\mathrm{Ca}}$ and $\Delta \Omega_{\mathrm{ar}}$ are -0.9 to $-1.06 \pm 0.15$ for calcite and -0.59 to $0.69 \pm 0.09$ for aragonite (Table 7). These results are consistent with those of Hassoun et al. (2015a). Nevertheless, despite the important acidification of the basin, Table 7 clearly shows that waters of the $\mathrm{AB}$ remain oversaturated with respect to calcite and aragonite throughout its water column, with mean saturation states of 2.4-4.5 and 1.6-2.9, respectively. These results agree with those of Álvarez et al. (2014) and Hassoun et al. (2015a) in the MS, and Chen et al. (2006b) in the South China Sea. In marginal seas, where waters have lower temperatures and 
TA than the MS, carbonate mineral undersaturation can be observed below $1000 \mathrm{~m}$ (e.g., Chen et al., 1995). Near calcite and aragonite saturation states were observed in the western $\operatorname{MS}\left(\Omega_{\mathrm{Ca}}=2.5\right.$ and $\left.\Omega_{\mathrm{Ar}}=1.5\right)$ during a cruise in 1976 (Millero et al., 1979). According to our results, $\mathrm{CaCO}_{3}$ oversaturation in the MS will probably persist for a few more centuries (Goyet et al., 2016). The increase in the $\mathrm{CaCO}_{3}$ saturation state of waters caused by temperature increase will partly compensate for water acidification as the stoichiometric solubility product of calcium carbonate $\left(\mathrm{K}^{*}\right)$ decreases with increasing temperatures caused by global warming, and the faster temperature increase in the MS.

\section{Conclusion}

This study, the first to cover the $A B$ in its entirety, was ased on a new dataset collected in the summer of 2014 (SOMBA cruise) to better unde' an 1 the carbonate chemistry and distribution of $\mathrm{C}^{\text {ant }}$ in the $\mathrm{AB}$. It revealed the nfluence of biological activity on the distribution patterns of TA and DIC (t. ${ }^{\top}$, photosynthesis and remineralization), in addition to the well-known surface east-west and ;o th-north gradients in the basin. During the summer of 2014 , the $\mathrm{AB}$ was a source $n \mathrm{CL}_{2}$ to the atmosphere, but the southwestern part of the basin was a $\mathrm{CO}_{2}$ sink because of in his ner biological activity, as corroborated by the high oxygen concentrations.

The vertical distribution of $\mathrm{C}^{\text {ant }}$ concentrations is related to the distribution of the main water masses and their respective ages. Nevertheless, this distribution is locally affected by active mesoscale and submesoscale processes in the $\mathrm{AB}$, processes that play an important role in enhancing carbon transport to deep waters. This paper also shows that the two tested approaches (MCM and TrOCA) yield relatively similar $\mathrm{C}^{\text {ant }}$ distributions and concentration ranges $(\sim 50-115 \mu \mathrm{mol} / \mathrm{kg})$. Nevertheless, the MCM requires a proper parametrization of the preindustrial air-sea disequilibrium because the latter generates high uncertainties on $\mathrm{C}^{\text {ant }}$ 
concentrations estimates in the $\mathrm{AB}$. Moreover, the preindustrial parametrization of $\mathrm{DIC}\left(\mathrm{C}^{0, \mathrm{PI}}\right)$ has to be assessed more rigorously for deep and intermediate waters, such as by including winter measurements of carbonate system parameters in the area of deep and intermediate water formation.

The sequestered $\mathrm{C}^{\text {ant }}$ inventory of the $\mathrm{AB}$ is about $0.44-0.53 \pm 0.06 \mathrm{Pg} \mathrm{C}$ (from the preindustrial era to 2014) and is mainly conditioned by the intrinsic characteristics of the MS, the bathymetry, and mesoscale processes in the region (anticyclnnic eddies). The accumulation of $\mathrm{C}^{\text {ant }}$ due to the increasing atmospheric $\mathrm{CO}_{2} \mathrm{cr}$ « $\mathrm{ntrations}$ and the quick renewal of deep waters (2005-2013) caused an acidificatic $n$ ra ging from -0.19 to $-0.1 \mathrm{pH}$ units. Nevertheless, the $\mathrm{AB}$ waters remain oversaturatf 4 vlin respect to calcite and aragonite. This oversaturation will probably persist as the incre.se oi sea surface temperatures partially compensates for the acidification.

\section{Acknowledgments}

The SOMBA-GE cruise was the p...tu of an Algerian/French collaboration under the MerMex program, promoted by the 1-MOOSE initiative within the framework of MISTRALS. We thank the $\mathrm{ca}_{\mathbf{r}}{ }^{*}$ ins and crew of the R/V Téthys, Benyahia Boudjellal, and Azzouz Mekki for their - vmmitment on-board. We are particularly grateful to the SNAPO$\mathrm{CO}_{2}$ laboratory, especially Jonathan Fin, Claire Lo Monaco, and Nicolas Metzl for their high quality measurements. We would also like to thank Dr. Sofiane Soukane for his help on a previous version of the manuscript. Comments from the two anonymous, journal reviewers and Associate Editor Alfonso Mucci helped enhance the quality of the manuscript, we warmly thank them. The SOMBA cruise and geochemical parameter measurements were funded by the French Ministry of foreign affairs (MAEDI) under the ENVIMED program [grant number 2014, 2834-CIRMED]. 


\section{References}

Aït-Ameur, N., Goyet, C., 2006. Distribution and transport of natural and anthropogenic $\mathrm{CO}_{2}$ in the Gulf of Cádiz. Deep Sea Research Part II: Topical Studies in Oceanography 53, 13291343. https://doi.org/10.1016/j.dsr2.2006.04.003

Álvarez, M., Lo Monaco, C., Tanhua, T., Yool, A., Oschlies, A., Bullister, J.L., Goyet, C., Tourtair, F., McDonagh, E., Bryden, H.L., 2009. Estimating the storage of anthropogenic carbon in the subtropical Indian Ocean: A comparison of five different approaches.

Biogeosciences (BG) 6, 681-703. https://doi.org/10.5194/bg-6-681-2009

Álvarez, M., Sanleón-Bartolomé, H., Tanhua, T., Mintrop, L., Luchetta, A., Cantoni, C., Schroeder, K., Civitarese, G., 2014. The $\mathrm{CO}_{2}$ system in the Me 'iterranean Sea: a basin wide perspective. Ocean Science. 10, 69-92. https $/ /$ doi.org/10.5194/ r-1 ?-69-2014

Anderson, L.A., 1995. On the hydrogen and oxygen content 1 t...rine phytoplankton. Deep Sea Research Part I: Oceanographic Research Papers 42, 1:75 1680.

https://doi.org/10.1016/0967-0637(95)00072-E

Bakun, A., Agostini, V.N., 2001. Seasonal patterns of vir.d-induced upwelling/downwelling in the Mediterranean Sea. Scientia Marina 65, 242 257.

Bégovic, M., Copin-Montégut, C., 2002. Proc sst sontrolling annual variations in the partial pressure of $\mathrm{CO}_{2}$ in surface waters of the $r$ ent) al rurthwestern Mediterranean Sea (Dyfamed site). Deep Sea Research Part II: Topical So 'dies in Oceanography 49, 2031-2047.

Benson, B.B., Krause, D., 1984. The con 'entration and isotopic fractionation of oxygen dissolved in freshwater and seawate ir cuilibrium with the atmosphere. Limnology and Oceanography 29,620-632. https / i i.urg/10.4319/lo.1984.29.3.0620

Béthoux, J.P., Morin, P., Ruiz-rîno, D.P., 2002. Temporal trends in nutrient ratios: chemical evidence of Mediterranean ecos stem changes driven by human activity. Deep Sea Research Part II: Topical Studies in ¿ emography 49, 2007-2016.

Bosse, A., Testor, P., h. 'luut, L., Damien, P., Prieur, L., Hayes, D., Taillandier, V., Durrieu de Madron, X., d'Orten-iin, F., Coppola, L., Karstensen, J., Mortier, L., 2016. Scales and dynamics of Submesoscale Coherent Vortices formed by deep convection in the northwestern Mediterranean Sea. Journal of Geophysical Research: Oceans 121, 7716-7742. https://doi.org/10.1002/2016JC012144

Chen, C.-T.A., 1993. Carbonate chemistry of the wintertime Bering Sea marginal ice zone. Continental Shelf Research 13, 67-87. https://doi.org/10.1016/0278-4343(93)90036-W

Chen, C.-T.A., Andreev, A., Kim, K.-R., Yamamoto, M., 2004. Roles of Continental Shelves and Marginal Seas in the Biogeochemical Cycles of the North Pacific Ocean. Journal of Oceanography 60, 17-44. https://doi.org/10.1023/B:JOCE.0000038316.56018.d4

Chen, C.-T.A., Hou, W.-P., Gamo, T., Wang, S.L., 2006a. Carbonate-related parameters of subsurface waters in the West Philippine, South China and Sulu Seas. Marine Chemistry, AQUACHEM — 04 99, 151-161. https://doi.org/10.1016/j.marchem.2005.05.008 
Chen, C.-T.A., Jones, E.P., Lin, K., 1990. Wintertime total carbon dioxide measurements in the Norwegian and greenland seas. Deep Sea Research Part A. Oceanographic Research Papers 37, 1455-1473. https://doi.org/10.1016/0198-0149(90)90137-K

Chen, G.-T., Millero, F.J., 1979. Gradual increase of oceanic $\mathrm{CO}_{2}$. Nature 277, 205-206. https://oi.org/10.1038/277205a0

Chen, C.T.A., Tsunogai, S., 1998. Carbon and nutrients in the ocean, in: Asian Change in the Context of Global Climate Change: Impact of Natural and Anthropogenic Changes in Asia on Global Biogeochemical Cycles. pp. 271-307.

Chen, C.-T.A., Wang, S.-L., Bychkov, A.S., 1995. Carbonate chemistry of the Sea of Japan. Journal of Geophysical Research: Oceans 100, 13737-13745.

https://doi.org/10.1029/95JC00939

Chen, C.-T.A., Wang, S.-L., Chou, W.-C., Sheu, D.D., 2006b curbunate chemistry and projected future changes in $\mathrm{pH}$ and $\mathrm{CaCO}_{3}$ saturation state of $\mathrm{L}_{\mathrm{s}}$; outh China Sea. Marine Chemistry 101, 277-305. https://doi.org/10.1016/j.marcher 2016.01 .007

[dataset] Copernicus Marine Environment Monitoring s $\sim$ rvise [WWW Document], 2017. Copernicus. URL http://marine.copernicus.eu/services nor.folio/access-to-products/ (accessed 3.20.17).

Copin-Montégut, C., Bégovic, M., 2002. Distrỉ $u_{\iota}{ }^{2} r_{\mathrm{s}}$ of carbonate properties and oxygen along the water column $(0-2000 \mathrm{~m})$ in the ce trai part of the NW Mediterranean Sea (Dyfamed site): influence of winter vertici: mixing on air-sea $\mathrm{CO}_{2}$ and $\mathrm{O}_{2}$ exchanges. Deep Sea Research Part II: Topical Studies $\sim$ Oceanography, Studies at the DYFAMED (France JGOFS) Time-Series Station, N.W. N i dituranean Sea 49, 2049-2066.

https://doi.org/10.1016/S0967-0645(U2 10 0027-9

Copin-Montégut, C., Bégovic, M., Merlivat, L., 2004. Variability of the partial pressure of $\mathrm{CO}_{2}$ on diel to annual time sc: ${ }^{\mathrm{l} e s}$ in the Northwestern Mediterranean Sea. Marine Chemistry 85, 169-189. https://doi.org/ i .11,16/j. marchem.2003.10.005

Coppola, L., Legendr . L. Lf ièvre, D., Prieur, L., Taillandier, V., Riquier, E.D., 2018. Seasonal and inter-annual variations of dissolved oxygen in the northwestern Mediterranean Sea (DYFAMED site). rrogress in Oceanography 162, 187-201.

Cossarini, G., Lazzari, P., Solidoro, C., 2015. Spatiotemporal variability of alkalinity in the Mediterranean Sea. Biogeosciences 12, 1647-1658. https://doi.org/10.5194/bg-12-1647-2015

Dickson, A.G., 1990. Thermodynamics of the dissociation of boric acid in synthetic seawater from 273.15 to 318.15 K. Deep Sea Research Part A. Oceanographic Research Papers 37, 755-766. https://doi.org/10.1016/0198-0149(90)90004-F

Dickson, A.G., Millero, F.J., 1987. A comparison of the equilibrium constants for the dissociation of carbonic acid in seawater media. Deep Sea Research Part A. Oceanographic Research Papers 34, 1733-1743. https://doi.org/10.1016/0198-0149(87)90021-5

Dickson, A.G., Sabine, C.L., Christian, J.R., 2007. Guide to best practices for ocean $\mathrm{CO}_{2}$ measurements, PICES Special Publication 3. ed, $191 \mathrm{pp}$. 
DOE, 1994. Handbook of Methods for the Analysis of the Various Parameters of the Carbon Dioxide System in Sea Water. Version 2 (No. ORNL/CDIAC-74). A. G. Dickson \& C. Goyet, eds. DOI: 10.2172/10107773.

D’Ortenzio, F., Antoine, D., Marullo, S., 2008. Satellite-driven modeling of the upper ocean mixed layer and air-sea $\mathrm{CO}_{2}$ flux in the Mediterranean Sea. Deep Sea Research Part I: Oceanographic Research Papers 55, 405-434. https://doi.org/10.1016/j.dsr.2007.12.008

Durrieu de Madron, X., Guieu, C., Sempéré, R., Conan, P., Cossa, D., D’Ortenzio, F., Estournel, C., Gazeau, F., Rabouille, C., Stemmann, L., Bonnet, S., Diaz, F., Koubbi, P., Radakovitch, O., Babin, M., Baklouti, M., Bancon-Montigny, C., Belviso, S., Bensoussan, N., Bonsang, B., Bouloubassi, I., Brunet, C., Cadiou, J.-F., Carlotti, F., Chami, M., Charmasson, S., Charrière, B., Dachs, J., Doxaran, D., Dutay, J.-C., Elbaz-Poulichet, F., Eléaume, M., Eyrolles, F., Fernandez, C., Fowler, S., Francour, P., Gaertner, J. . , Galzin, R., Gasparini, S., Ghiglione, J.-F., Gonzalez, J.-L., Goyet, C., Guidi, L., Guizier K. Heimbürger, L.-E., Jacquet, S.H.M., Jeffrey, W.H., Joux, F., Le Hir, P., Leblarr, K., Lefêvre, D., Lejeusne, C., Lemé, R., Loÿe-Pilot, M.-D., Mallet, M., Méjanelle, L., M M iin F., Mellon, C., Mérigot, B.,

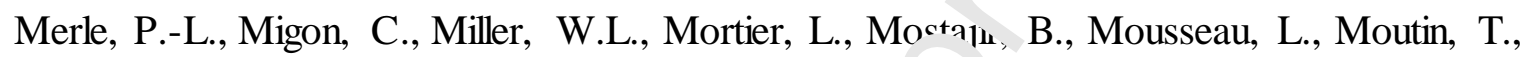
Para, J., Pérez, T., Petrenko, A., Poggiale, J.-C., Prieı. L Pujo-Pay, M., Pulido-Villena, Raimbault, P., Rees, A.P., Ridame, C., Rontani, J.-F., Ruk Pino, D., Sicre, M.A., Taillandier, V., Tamburini, C., Tanaka, T., Taupier-Letage, 1 , iє letti, M., Testor, P., Thébault, H., Thouvenin, B., Touratier, F., Tronczynski, I, S'lses, C., Van Wambeke, F., Vantrepotte, V., Vaz, S., Verney, R., 2011. Marine ecosy: 'er,' responses to climatic and anthropogenic forcings in the Mediterranean. Progress in U a anography 91, 97-166.

https://doi.org/10.1016/j.pocean.2011.0'․? 03

Edmond, J.M., 1970. High precision d tf rmination of titration alkalinity and total carbon dioxide content of sea water by f'iteniometric titration. Deep Sea Research and Oceanographic Abstracts 17, 7:7-\% j0. https://doi.org/10.1016/0011-7471(70)90038-0

Flecha, S., Pérez, F.F., Nava ‘ro, J., Ruiz, J., Olivé, I., Rodríguez-Gálvez, S., Costas, E., Huertas, I.E., 2012. Anth opc renic carbon inventory in the Gulf of Cádiz. Journal of Marine Systems 92, 67-75. htt, \%//uv1.org/10.1016/j.jmarsys.2011.10.010

Friis, K., 2006. A review of marine anthropogenic $\mathrm{CO}_{2}$ definitions: introducing a thermodynamic approach based on observations. Tellus B: Chemical and Physical Meteorology 58, 2-15. https://doi.org/10.1111/j.1600-0889.2005.00173.x

Friis, K., Körtzinger, A., Wallace, D.W.R., 2003. The salinity normalization of marine inorganic carbon chemistry data. Geophys. Res. Lett. 30, 1085.

https://doi.org/10.1029/2002GL015898

[dataset] GEBCO [WWW Document], 2019. British Oceanographic Data Centre. URL https://www.bodc.ac.uk/data/hosted_data_systems/gebco_gridded_bathymetry_data/ (accessed 3.26.19).

Gemayel, E., Hassoun, A.E.R., Benallal, M.A., Goyet, C., Rivaro, P., Saab, M.A.-A., Krasakopoulou, E., Touratier, F., Ziveri, P., 2015. Climatological variations of total alkalinity 
and total inorganic carbon in the Mediterranean Sea surface waters. Earth System Dynamics Discussions 6. https $/ /$ doi.org/10.5194/esd-6-789-2015

Goyet, C., Davis, D., 1997. Estimation of total $\mathrm{CO}_{2}$ concentration throughout the water column. Deep Sea Research Part I: Oceanographic Research Papers 44, 859-877. https://doi.org/10.1016/S0967-0637(96)00111-2

Goyet, C., Hassoun, A., Gemayel, E., Touratier, F., Saab, M.A.-A., Guglielmi, V., 2016. Thermodynamic Forecasts of the Mediterranean Sea Acidification. Mediterranean Marine Science 17, 508-518. https://doi.org/10.12681/mms.1487

Gruber, N., Sarmiento, J.L., Stocker, T.F., 1996. An improved method for detecting anthropogenic $\mathrm{CO}_{2}$ in the oceans. Global Biogeochemical Cycles 10, 809-837. https://doi.org/10.1029/96GB01608

Hainbucher, D., Rubino, A., Cardin, V., Tanhua, T., Schroede', I. , Bensi, M., 2014. Hydrographic situation during cruise M84/3 and P414 (sprino 2n1 1 ) in the Mediterranean Sea. Ocean Sci. 10, 669-682. https://doi.org/10.5194/os-10 66 -2014

Hassoun, A.E.R., Gemayel, E., Krasakopoulou, E., Gr j- S., Abboud-Abi Saab, M., Guglielmi, V., Touratier, F., Falco, C., 2015a. Acidific.tin .1 of the Mediterranean Sea from anthropogenic carbon penetration. Deep Sea Researcı Parı I: Oceanographic Research Papers 102, 1-15. https://doi.org/10.1016/j.dsr.2015.04.1\%J

Hassoun, A.E.R., Gemayel, E., Krasakop ulc 1, I, Goyet, C., Saab, M.A.-A., Ziveri, P., Touratier, F., Guglielmi, V., Falco, C., 2vi ${ }^{\circ}$ o. Modeling of the Total Alkalinity and the Total Inorganic Carbon in the Mediterraneaı Sea. Journal of Water Resources and Ocean Science 24-32. https://doi.org/10.11648/j.wro ..201_0401.14

Hood, E.M., Merlivat, L., 2001. f.n. 'lai to interannual variations of $\mathrm{fCO}_{2}$ in the northwestern Mediterranean Sea: Results fror i is 'urly measurements made by CARIOCA buoys, 1995-

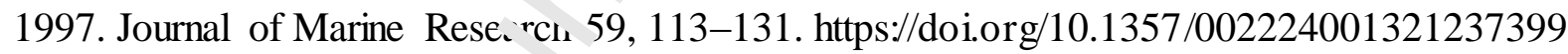

Houpert, L., 2013. Contripritio: to the Study of Transfer Processes from the Surface to the Deep Ocean in the M. dit rar zan Sea using in situ Measurements (thesis). Université de Perpignan Via Domitia, $r$, ance.

Huertas, I.E., Ríos, A.F., García-Lafuente, J., Makaoui, A., Rodríguez-Gálvez, S., SánchezRomán, A., Orbi, A., Ruíz, J., Pérez, F.F., 2009. Anthropogenic and natural $\mathrm{CO}_{2}$ exchange through the Strait of Gibraltar. Biogeosciences 6, 647-662. https $/ /$ doi.org/10.5194/b g-6-6472009

Jutterström, S., Jeansson, E., Anderson, L.G., Bellerby, R., Jones, E.P., Smethie, W.M., Swift, J.H., 2008. Evaluation of anthropogenic carbon in the Nordic Seas using observed relationships of N, P and C versus CFCs. Progress in Oceanography 78, 78-84. https://doi.org/10.1016/j.pocean.2007.06.001

[dataset] Kanamitsu, M., Ebisuzaki, W., Woollen, J., Yang, S.-K., Hnilo, J.J., Fiorino, M., Potter, G.L., 2002. NCEP-DOE AMIP-II Reanalysis (R-2). 
Kessouri, F., Ulses, C., Estournel, C., Marsaleix, P., D’Ortenzio, F., Severin, T., Taillandier, V., Conan, P., 2018. Vertical Mixing Effects on Phytoplankton Dynamics and Organic Carbon Export in the Western Mediterranean Sea. Journal of Geophysical Research: Oceans 123, 1647-1669. https://doi.org/10.1002/2016JC012669

Körtzinger, A., Hedges, J.I., Quay, P.D., 2001. Redfield ratios revisited: Removing the biasing effect of anthropogenic $\mathrm{CO}_{2}$. Limnology and Oceanography 46, 964-970. https://doi.org/10.4319/lo.2001.46.4.0964

La Ferla, R., Azzaro, M., Civitarese, G., Ribera d'Alcalà, M., 2003. Distribution patterns of carbon oxidation in the eastern Mediterranean Sea: Evidence of changes in the remineralization processes. J. Geophys. Res. 108, 8111. https://doi.org/10.1029/2002JC001602

Langdon, C., 2010. Determination of dissolved oxygen in seawater hy Winkler titration using the amperometric technique (No. IOCCP Report Number 14. ICP) Publication Series Number 134). The GOSHIP Repeat Hydrography Manual: a ( )llection of Expert Reports and Guidelines, edited by: Hood, EM, Sabine, CL, and Sloya", biv1.

Lee, K., Sabine, C.L., Tanhua, T., Kim, T.-W., Feely, R.A, Kim, H.-C., 2011. Roles of marginal seas in absorbing and storing fossil fuel $\mathrm{CO}_{2}$. L argy Environ. Sci. 4, 1133-1146. https://doi.org/10.1039/C0EE00663G

Lee, K., Tong, L.T., Millero, F.J., Sabine, $C$ L., Dickson, A.G., Goyet, C., Park, G.-H., Wanninkhof, R., Feely, R.A., Key, R.M., 20' 6 . Global relationships of total alkalinity with salinity and temperature in surface waters of se world's oceans. Geophys. Res. Lett. 33, L19605. https://doi.org/10.1029/2006GLi?7207

Lo Monaco, C., Metzl, N., Poisson A I,runet, C., Schauer, B., 2005. Anthropogenic $\mathrm{CO}_{2}$ in the Southern Ocean: Distribution and inventory at the Indian-Atlantic boundary (World Ocean Circulation Experiment line I6). Iournal of Geophysical Research: Oceans 110. https://doi.org/10.1029/2004 ICU`?643

Louanchi, F., Boudjakdji, M. Nacef, L., 2009. Decadal changes in surface carbon dioxide and related variables in the 1 aterranean Sea as inferred from a coupled data-diagnostic model approach. ICES J Mar $\cong$ \%6, 1538-1546. https://doi.org/10.1093/icesjms/fsp049

Lovato, T., Vichi, M., 2015. An objective reconstruction of the Mediterranean Sea carbonate system. Deep Sea Research Part I: Oceanographic Research Papers 98, 21-30. https://doi.org/10.1016/j.dsr.2014.11.018

Malanotte-Rizzoli, P., Artale, V., Borzelli-Eusebi, G.L., Brenner, S., Crise, A., Gacic, M., Kress, N., Marullo, S., Ribera d'Alcalà, M., Sofianos, S., Tanhua, T., Theocharis, A., Alvarez, M., Ashkenazy, Y., Bergamasco, A., Cardin, V., Carniel, S., Civitarese, G., D’Ortenzio, F., Font, J., Garcia-Ladona, E., Garcia-Lafuente, J.M., Gogou, A., Gregoire, M., Hainbucher, D., Kontoyannis, H., Kovacevic, V., Kraskapoulou, E., Kroskos, G., Incarbona, A., Mazzocchi, M.G., Orlic, M., Ozsoy, E., Pascual, A., Poulain, P.-M., Roether, W., Rubino, A., Schroeder, K., Siokou-Frangou, J., Souvermezoglou, E., Sprovieri, M., Tintoré, J., Triantafyllou, G., 2014. Physical forcing and physical/biochemical variability of the Mediterranean Sea: a 
review of unresolved issues and directions for future research. Ocean Science 10, 281-322. https://doi.org/10.5194/os-10-281-2014

Marcellin Yao, K., Marcou, O., Goyet, C., Guglielmi, V., Touratier, F., Savy, J.-P., 2016. Time variability of the north-western Mediterranean Sea pH over 1995-2011. Marine Environmental Research 116, 51-60. https://doi.org/10.1016/j.marenvres.2016.02.016

Mehrbach, C., Culberson, C.H., Hawley, J.E., Pytkowicx, R.M., 1973. Measurement of the Apparent Dissociation Constants of Carbonic Acid in Seawater at Atmospheric Pressure 1. Limnol. Oceanogr. 18, 897-907. https://doi.org/10.4319/lo.1973.18.6.0897

Merlivat, L., Boutin, J., Antoine, D., Beaumont, L., Golbol, M., Vellucci, V., 2018. Increase of dissolved inorganic carbon and decrease in $\mathrm{pH}$ in near-surface waters in the Mediterranean Sea during the past two decades. Biogeosciences 15, 5653-566 ?. https://doi.org/10.5194/bg15-5653-2018

Millero, F.J., Lee, K., Roche, M., 1998. Distribution of alkalin I.: in the surface waters of the major oceans. Marine Chemistry 60, 111-130. https:/doi o. o/11 .1016/S0304-4203(97)000844

Millero, F.J., Morse, J., Chen, C.-T., 1979. The carbo. ^te system in the western Mediterranean Sea. Deep Sea Research Part A. Oreanographic Research Papers 26, 13951404. https://doi.org/10.1016/0198-0149(79)900) 7-4

Millot, C., Taupier-Letage, I., 2005. Circrat $n$ in the Mediterranean Sea, in: Saliot, A. (Ed.), The Mediterranean Sea, Handbook of Env nmental Chemistry. Springer Berlin Heidelberg, pp. 29-66. https://doi.org/10.1007/b16?7143

Morales-Pineda, M., Cózar, A., Laiz I, 'ŕbeda, B., Gálvez, J.Á., 2014. Daily, biweekly, and seasonal temporal scales of $\mathrm{pCO}_{2}$ variaulity in two stratified Mediterranean reservoirs.

Journal of Geophysical Researc'i: 2iogeosciences 119, 509-520.

https://doi.org/10.1002/2013JCへ) ?317

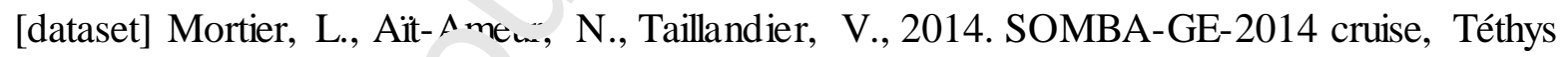
II R/V. https://oi.org'10. 76 (0/14007500

Moutin, T., Prieur, L., 2012. Influence of anticyclonic eddies on the biogeochemistry from the Oligotrophic to the ultraoligotrophic Mediterranean (BOUM cruise). Biogeosciences 9, 38273855. https://doi.org/10.5194/bg-9-3827-2012

Olsen, A., Omar, A.M., Jeansson, E., Anderson, L.G., Bellerby, R.G.J., 2010. Nordic seas transit time distributions and anthropogenic $\mathrm{CO}_{2}$. Journal of Geophysical Research: Oceans 115. https://doi.org/10.1029/2009JC005488

Palmiéri, J., Orr, J.C., Dutay, J.-C., Béranger, K., Schneider, A., Beuvier, J., Somot, S., 2015. Simulated anthropogenic $\mathrm{CO}_{2}$ storage and acidification of the Mediterranean Sea.

Biogeosciences (BG) 12, 781-802. https://doi.org/10.5194/bg-12-781-2015

Park, G.-H., Lee, K., Tishchenko, P., Min, D.-H., Warner, M.J., Talley, L.D., Kang, D.-J., Kim, K.-R., 2006. Large accumulation of anthropogenic $\mathrm{CO}_{2}$ in the East (Japan) Sea and its 
significant impact on carbonate chemistry. Global Biogeochemical Cycles 20. https://doi.org/10.1029/2005GB002676

Pessini, F., Olita, A., Cotroneo, Y., Perilli, A., 2018. Mesoscale eddies in the Algerian Basin: do they differ as a function of their formation site? Ocean Science 14, 669-688. https://doi.org/10.5194/os-14-669-2018

Pierrot, D., Lewis, E., Wallace, D.W.R., 2006. MS Excel Program Developed for $\mathrm{CO}_{2}$ System Calculations. ORNL/CDIAC-105a. doi: 10.3334/CDIAC/otg.COSYS_XLS_CDIAC105a.

Puig, P., Salat, J., Martín, J., Palanques, A., Emelianov, M., 2013. Thick bottom nepheloid layers in the western Mediterranean generated by deep dense shelf water cascading. https://doi.org/10.1016/j.pocean.2012.10.003

Rivaro, P., Messa, R., Massolo, S., Frache, R., 2010. Distributio, of carbonate properties along the water column in the Mediterranean Sea: Spatial and noial variations. Marine Chemistry 121, 236-245. https://doi.org/10.1016/j.marchem $x^{\prime} !^{\prime}{ }^{\prime} 5.003$

Sabine, C.L., Tanhua, T., 2010. Estimation of Anthropog $\mathrm{m}_{\mathrm{L}} \mathrm{CO}_{2}$ Inventories in the Ocean. Annual Review of Marine Science 2, 175-198. https://\%: ${ }^{\circ} \cdot \mathrm{g} / 10.1146 /$ annure v- marine120308-080947

SBE, 2010. SBE 43 Dissolved Oxygen Sensor C All ration and Data Corrections using Winkler Titrations (APPLICATION NOTE N(..1-2). Sea-Bird Electronics, Inc., $13431 \mathrm{NE}$ 20th Street Bellevue, WA 98005, USA.

Schlitzer, R., Ocean Data View, odv.awi.de, 9018

Schneider, A., Tanhua, T., Körtzinger A., Wallace, D.W.R., 2010. High anthropogenic carbon content in the eastern Mediteirs ne an. J. Geophys. Res. 115, C12050.

https://doi.org/10.1029/2010JC00(.1\% i

Schroeder, K., Josey, S.A., Hen ^əann, M., Grignon, L., Gasparini, G.P., Bryden, H.L., 2010. Abrupt warming and salting of t心 Western Mediterranean Deep Water after 2005: Atmospheric forcings anr. là ral advection. Journal of Geophysical Research 115.

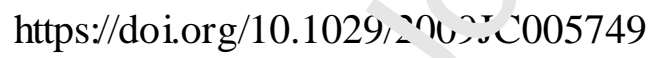

Schroeder, K., Ribotti, ז.., Borghini, M., Sorgente, R., Perilli, A., Gasparini, G.P., 2008. An extensive western Mediterranean deep water renewal between 2004 and 2006. Geophys. Res. Lett. 35, L18605. https://doi.org/10.1029/2008GL035146

Sisma-Ventura, G., Yam, R., Kress, N., Shemesh, A., 2016. Water column distribution of stable isotopes and carbonate properties in the South-eastern Levantine basin (Eastern Mediterranean): Vertical and temporal change. Journal of Marine Systems 158, 13-25. https://doi.org/10.1016/j.jmarsys.2016.01.012

Swift, J.H., 2010. Reference-quality water sample data: notes on acquisition, record keeping, and evaluation (The GO-SHIP Repeat Hydrography Manual: A collection of expert Reports and Guidlines No. IOCCP Report N14). 
Taillandier, V., D’Ortenzio, F., Antoine, D., 2012. Carbon fluxes in the mixed layer of the Mediterranean Sea in the 1980s and the 2000s. Deep Sea Research Part I: Oceanographic Research Papers 65, 73-84. https://doi.org/10.1016/j.dsr.2012.03.004

Testor, P., Gascard, J.C., 2003. Large-scale spreading of deep waters in the Western Mediterranean Sea by submesoscale coherent eddies. Journal of physical oceanography 33, 75-87. https://doi.org/10.1175/1520-0485(2003)033<0075:LSSODW>2.0.CO;2

Testor, P., Send, U., Gascard, J.-C., Millot, C., Taupier-Letage, I., Béranger, K., 2005. The mean circulation of the southwestern Mediterranean Sea: Algerian Gyres. J. Geophys. Res. 110, C11017. https://doi.org/10.1029/2004JC002861

Touratier, F., Azouzi, L., Goyet, C., 2007. CFC $-11,{ }^{14} \mathrm{C}$ and ${ }^{3} \mathrm{H}$ tracers as a means to assess anthropogenic $\mathrm{CO}_{2}$ concentrations in the ocean. Tellus B 59, 318-325.

https://doi.org/10.1111/j.1600-0889.2006.00247.x

Touratier, F., Goyet, C., 2004. Applying the new TrOCA appi act to assess the distribution of anthropogenic $\mathrm{CO}_{2}$ in the Atlantic Ocean. Journal of Mi rine Systems 46, 181-197. https://doi.org/10.1016/j.jmarsys.2003.11.020

Touratier, F., Goyet, C., 2011. Impact of the Eastern Med erranean Transient on the distribution of anthropogenic $\mathrm{CO}_{2}$ and first estimate of a idification for the Mediterranean Sea. Deep Sea Research Part I: Oceanographic Fes ż rch Papers 58, 1-15.

https://doi.org/10.1016/j.dsr.2010.10.002

Touratier, F., Goyet, C., 2009. Decadal c rol cion of anthropogenic $\mathrm{CO}_{2}$ in the northwestern Mediterranean Sea from the mid-1990s to the mid-2000s. Deep Sea Research Part I:

Oceanographic Research Papers 56, 170c -1716. https://doi.org/10.1016/j.dsr.2009.05.015

Touratier, F., Goyet, C., Houpert, I., ( e Madron, X.D., Lefêvre, D., Stabholz, M., Guglielmi, V., 2016. Role of deep convectio: on anthropogenic $\mathrm{CO}_{2}$ sequestration in the Gulf of Lions (northwestern Mediterranean S $\mathrm{S}^{\urcorner}$). Deep Sea Research Part I: Oceanographic Research Papers 113, 33-48. https $/ /$ doi.org/10.16 :5/j.dsr.2016.04.003

Touratier, F., Guglielmi, V., ' Toyet, C., Prieur, L., Pujo-Pay, M., Conan, P., Falco, C., 2012. Distributions of the carc nate system properties, anthropogenic $\mathrm{CO}_{2}$, and acidification during the 2008 BOUM cruise iediterranean Sea). Biogeosciences Discussions 9, 2709-2753. https://doi.org/10.5194/bgd-9-2709-2012

Tréguer, P., LeCorre, P., 1975. Manuel d'analyse des sels nutritifs dans l'eau de mer. Utilisation de l'AutoAnalyser II Technicon, 2nd ed. ed. Univ. Bretagne Occidentale, Laboratoire de Chimie marine, Brest, France.

Uppström, L.R., 1974. The boron/chlorinity ratio of deep-sea water from the Pacific Ocean. Deep Sea Research and Oceanographic Abstracts 21, 161-162. https://doi.org/10.1016/00117471(74)90074-6

Vázquez-Rodríguez, M., Touratier, F., Lo Monaco, C., Waugh, D.W., Padin, X.A., Bellerby, R.G.J., Goyet, C., Metzl, N., Ríos, A.F., Pérez, F.F., 2009. Anthropogenic carbon distributions in the Atlantic Ocean: data-based estimates from the Arctic to the Antarctic. Biogeosciences 6, 439-451. https://doi.org/10.5194/bg-6-439-2009 
[dataset] WDCGG [WWW Document], 2018. World Data Centre for Greenhous Gases. URL https://gaw.kishou.go.jp/ (accessed 4.23.18).

Weiss, R.F., Price, B.A., 1980. Nitrous oxide solubility in water and seawater. Marine Chemistry 8, 347-359. https://doi.org/10.1016/0304-4203(80)90024-9

Yool, A., Oschlies, A., Nurser, A.J.G., Gruber, N., 2010. A model-based assessment of the TrOCA approach for estimating anthropogenic carbon in the ocean. Biogeosciences 7, 723751. https://doi.org/10.5194/bg-7-723-2010 


\section{Figures captions}

Fig. 1: The distribution of SOMBA cruise stations (white dots correspond to the sampled stations for TA/DIC). The base map represents the Mediterranean Sea gridded Sea Level Anomaly all-sat-merged (L4), expressed in meters for August 16, 2014. Downloaded from Copernicus Marine Environment Monitoring Service website ("Copernicus Marine Environment Monitoring Service," 2017). (color should be used for this figure in print)

Fig. 2: Vertical variability of Total Alkalinity (a) and Dissolved Inorganic Carbon (b) residuals using the proposed equations. SDr is the Standard Deviation of the residuals. (color should not be used for this figure in print)

Fig. 3: Theta/Practical Salinity $\left(\theta / S_{\mathrm{p}}\right)$ diagrams for the entire water ( ${ }^{1} u m n(a)$; the intermediate layer (b); the deep layer (c). The color bar scales depict longitude in degrees $1 . r$ (a) and (b), and Apparent Oxygen Utilization for (c). (d) is the vertical distribution of salinity alor $g$ an east-west section during the SOMBA cruise. AW/MAW: Atlantic Waters/Modified Atls atic Waters; LIW: Levantine Intermediate Waters; WIW: Winter Intermediate Waters; WN iL Western Mediterranean Deep Waters; WMDWn: newly formed Western Mediterranean ${ }^{n} \wedge_{\mu}$ Waters. (color should be used for this figure in print)

Fig. 4: Boxplots of TA (a), DIC (b), $\mathrm{pH}_{\mathrm{T}}$ (c) and $p \mathrm{C}_{2}$ (d) for the SOMBA cruise data over three depth layers (surface, intermediate, and deep). The $\mathrm{t}$ - $\mathrm{li}$ nits correspond to the first quartile, median, and third quartile, respectively; the straight lir $\mathrm{re}_{\mathrm{r}}$-esents the minimum and maximum; the black dots are the outliers; the diamond dots corr $\sim \mathrm{no}^{\prime} \mathrm{d}$ to the mean values. (color should not be used for this figure in print)

Fig. 5: Surface distribution of TA (a), salinn, normalized TA (b), DIC (c), salinity-normalized DIC (d), $\mathrm{pH}_{\mathrm{T}}(\mathrm{e}), \triangle p \mathrm{CO}_{2}$ (f), oxygen saturai o ( (3) and practical salinity (h) during the SOMBA cruise. (color should be used for this figu e s. print)

Fig. 6: The vertical distributions $f$ the non-normalized and salinity-normalized TA (a and b, respectively) and DIC (c and d, rc nectively) along an east-west section during the SOMBA cruise. (color should be used for this :- are in print)

Fig. 7: The mean longituci 'rl (a, b, c, d) and latitudinal (e, f, g, h) evolution of the non-normalized

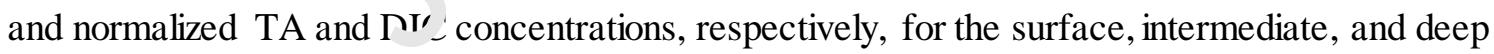
layers. The error bars correspond with the standard deviation and the dashed line is the mean linear trend with its confidence interval (in gray). (color should not be used for this figure in print)

Fig. 8: The vertical distribution along an east-west section of: (a) anthropogenic carbon concentration computed by the TrOCA approach; (b) anthropogenic carbon concentration computed by the MCM; (c) Apparent Oxygen Utilization (color should be used for this figure in print)

Fig. 9: The distribution of anthropogenic carbon inventory in the Algerian Basin using two approaches; the TrOCA (orange) and the MCM (yellow). The numbers correspond to box identification numbers and the blue scale bar to bathymetry. (color should not be used for this figure in print)

Fig. 10: East-west vertical distribution of $\Delta \mathrm{pH}$ computed using anthropogenic carbon concentration values of the MCM (a) and the TrOCA (b) approaches. (color should be used for this figure in print) 
Table 1: Monthly mean atmospheric carbon dioxide dry air mole fraction for the selected stations for $\mathrm{CO}_{2}$ survey for August and September 2014

\begin{tabular}{|c|c|c|c|c|}
\hline \multirow{2}{*}{$\begin{array}{c}\text { Measurement } \\
\text { stations_code_country }\end{array}$} & \multirow[t]{2}{*}{ Location (lat/long) } & \multirow{2}{*}{$\begin{array}{l}\text { Sampling } \\
\text { altitude (m) }\end{array}$} & \multicolumn{2}{|c|}{$\begin{array}{c}\text { Monthly mean } \mathrm{xCO}_{2} \text { values } \\
\text { (ppm) } \pm \text { uncertainty (SD) }\end{array}$} \\
\hline & & & 17-31 August & 01-08 Se ptember \\
\hline $\begin{array}{l}\text { Monte Cimone_ } \\
\text { CMN_Italy }\end{array}$ & $44.16^{\circ} \mathrm{E} / 10.68^{\circ} \mathrm{E}$ & 2177 & $388.55 \pm 2.22$ & $391.51 \pm 2.21$ \\
\hline Plateau Rosa_PRS_Italy & $45.93^{\circ} \mathrm{N} / 7.7^{\circ} \mathrm{E}$ & 3490 & $390.62 \pm 0.54$ & $391.37 \pm 0.96$ \\
\hline $\begin{array}{l}\text { Puy du dome_- } \\
\text { PUY_France }\end{array}$ & $45.77^{\circ} \mathrm{N} / 2.96$ & 1475 & $387.82 \pm 2.88$ & $393.32 \pm 2.16$ \\
\hline Lampedusa_LMP_Italy & $35.52^{\circ} \mathrm{N} / 12.62^{\circ} \mathrm{E}$ & 50 & $390.24 \pm 2.25$ & $395.09 \pm 0.02$ \\
\hline Assekrem_ASK_Algeria & $23.26^{\circ} \mathrm{N} / 5.63^{\circ} \mathrm{E}$ & 2715 & $393.93 \pm 0.64$ & $394.75 \pm 0.14$ \\
\hline Begure_BGU_Spain & $3.23^{\circ} \mathrm{E} / 41.97^{\circ} \mathrm{N}$ & 13 & $391.81 \pm 3.51$ & 398.32 \\
\hline \multicolumn{3}{|c|}{ Mean (all data) } & $\begin{array}{c}390 \pm 2.8 \\
N=56 \text { values }\end{array}$ & $\begin{array}{c}393 \pm 2.4 \\
\mathrm{~N}=23 \text { values }\end{array}$ \\
\hline
\end{tabular}

SD: Standard Deviation $\mathrm{N}=$ number of con ${ }^{\mathrm{i}} \mathrm{e}, \mathrm{d}$ measurements to compute the mean 
Table 2: The estimated errors related to anthropogenic carbon calculation using the Modified

Chen and Millero approach (MCM)

\begin{tabular}{|c|c|c|}
\hline Error ( $\sigma)$ & Value & Assessment method \\
\hline$\sigma_{\mathrm{O}_{2}}$ & $1.6 \mu \mathrm{mol} / \mathrm{kg}$ & Measurement precision of dissolved oxygen \\
\hline$\sigma_{\mathrm{O}_{2}^{0}}$ & $4.9 \mu \mathrm{mol} / \mathrm{kg}$ & $\begin{array}{l}\text { RMSD of the preformed oxygen estimated between the selected and } \\
\text { the sensitivity test's parametrization (Table } 3.1 \text { ) }\end{array}$ \\
\hline$\sigma_{\mathrm{TA}}$ & $2 \mu \mathrm{mol} / \mathrm{kg}$ & Measurement precision of Total Alkalinity \\
\hline$\sigma_{\mathrm{TA}^{0}}$ & $7.5 \mu \mathrm{mol} / \mathrm{kg}$ & RMSD of equation 11 \\
\hline$\sigma_{\text {DIC }}$ & $3.3 \mu \mathrm{mol} / \mathrm{kg}$ & Measurement precision of Dissolved Inorganic Carbon \\
\hline$\sigma_{\mathrm{C}^{0, \mathrm{PI}}}$ & $3 \mu \mathrm{mol} / \mathrm{kg}$ & 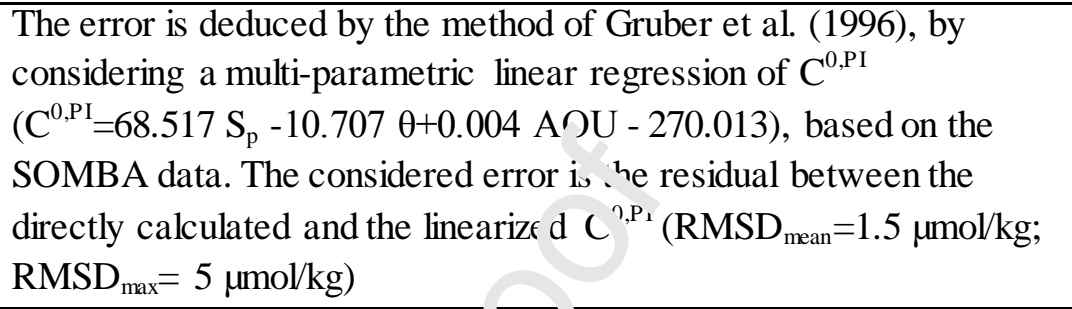 \\
\hline$\sigma_{\frac{C}{O_{2}}}$ & 0.0816 & \multirow{2}{*}{$\begin{array}{l}\text { The error is estimated by err - propagation of the uncertainties on } \mathrm{C} \text {, } \\
\mathrm{N} \text { and } \mathrm{O}_{2} \text {, given by Ander } \mathrm{OH}_{1} \text { ' } 1995 \text { ) }\end{array}$} \\
\hline$\sigma_{\bar{N}}$ & 0.0097 & \\
\hline
\end{tabular}

$\mathrm{O}_{2}$ : dissolved oxygen; $\mathrm{O}_{2}{ }^{0}$ : preformer. . "ssolved oxygen; TA: Total Alkalinity; TA $^{0}$ : preformed preindustrial Total Alka ${ }^{1}{ }^{*}+v$; DIC: Dissolved Inorganic Carbon; $\mathrm{C}^{0, \mathrm{PI}}$ : preformed preindustrial DIC; $\sim^{\prime} \cdot \mathrm{O}_{2} \cdot$ nd N/O $\mathrm{O}_{2}$ : Molar ratios; RMSD: Root Mean Square Deviation 
Table 3: (1) Root Mean Square Deviation (RMSD) between the values of the selected and the sensitivity tests' parametrizations for the parameters $\mathrm{O}_{2}{ }^{0}$, $\mathrm{TA}^{0}$, and $\mathrm{C}^{0, \mathrm{PI}}$; (2) RMSD of anthropogenic carbon values between the selected and the sensitivity tests' parametrizations.

\begin{tabular}{|c|c|c|c|c|c|c|c|}
\hline & & $\begin{array}{l}\text { Molar } \\
\text { Ratio } \\
\end{array}$ & $\mathbf{O}_{2}{ }^{0}$ & $\mathbf{T A}^{0}{ }_{-} \mathbf{1}$ & $\mathbf{T A}^{0}{ }_{2}$ & $\mathrm{TA}^{0}{ }_{-}$mean & $\mathbf{C}^{0, \text { PI }}$ \\
\hline \multirow[t]{2}{*}{1} & $\begin{array}{c}\text { RMSD of the } \\
\text { parame ters } \\
(\mu \mathrm{mol} / \mathrm{kg})\end{array}$ & - & 4.87 & 5.05 & 16.59 & 10.51 & 9.38 \\
\hline & $\mathbf{N}$ & - & 1013 & 1022 & 1022 & 1022 & 618 \\
\hline \multirow[t]{2}{*}{2} & $\begin{array}{c}\text { RMSD of C }^{\text {ant }} \\
(\mu \mathrm{mol} / \mathrm{kg})\end{array}$ & 2.2 & 3.8 & 0.98 & 5.27 & 3.1 & 9.35 \\
\hline & $\mathbf{N}$ & 618 & 618 & 618 & 618 & 618 & 618 \\
\hline
\end{tabular}

$\mathrm{N}$ is the number of the considered values; $\mathrm{O}_{2}{ }^{0}$ is the preforme ${ }^{*}$ preindustrial oxygen; $\mathrm{TA}^{0}{ }_{-} 1$ and $\mathrm{TA}^{0} \_2$ are the tested preformed, preindustrial Alkalinitie reci.ced from the proposed equations of Hassoun et al. (2015b), and Copin-Montégut a.d B igovic (2002), respectively. $\mathrm{TA}^{0}{ }_{-}$mean is the mean value of $\mathrm{TA}^{0}{ }_{-} 1$ and $\mathrm{TA}^{0}{ }_{2} ; \mathrm{C}^{0, \mathrm{PI}}$ is $\mathrm{t}_{\mathrm{L}}$ ? preformed, preindustrial DIC 
Table 4: Descriptive statistics on anthropogenic carbon concentrations using the TrOCA and the MCM approaches in addition to sensitivity tests results (sen1: preformed oxygen; sen2: molar ratios; sen3 and 4: preformed TA; sen5: air-sea disequilibrium)

\begin{tabular}{|c|c|c|c|c|c|c|c|}
\hline & $\begin{array}{l}\mathrm{C}^{\text {ant }} \text { TrOCA } \\
(\mu \mathrm{mol} / \mathrm{kg})\end{array}$ & $\begin{array}{l}\mathrm{C}^{\text {ant }} \mathrm{MCM} \\
(\mu \mathrm{mol} / \mathrm{kg})\end{array}$ & $\begin{array}{c}\mathrm{C}^{\text {ant }} \text { _sen1 } \\
(\mu \mathrm{mol} / \mathrm{kg})\end{array}$ & $\begin{array}{l}\mathrm{C}^{\text {ant }}-\operatorname{sen} 2 \\
(\mu \mathrm{mol} / \mathrm{kg})\end{array}$ & $\begin{array}{l}\mathrm{C}^{\text {ant }}-\operatorname{sen} 3 \\
(\mu \mathrm{mol} / \mathrm{kg})\end{array}$ & $\begin{array}{l}\mathrm{C}^{\text {ant }}-\operatorname{sen} 4 \\
(\mu \mathrm{mol} / \mathrm{kg})\end{array}$ & $\begin{array}{l}\mathrm{C}^{\text {ant }}-\operatorname{sen} 5 \\
(\mu \mathrm{mol} / \mathrm{kg})\end{array}$ \\
\hline Min. & 61 & 50 & 46 & 47 & 50 & 55 & 40 \\
\hline Mean & 81 & 69 & 65 & 67 & 70 & 74 & 59 \\
\hline SD & 4.3 & 5.2 & 5.2 & 5.2 & 5.3 & 5.2 & 5.2 \\
\hline Max. & 115 & 109 & 105 & 108 & 111 & 114 & 100 \\
\hline
\end{tabular}

Min: Minimum, Max: Maximum, SD: Standard Deviation 
Table 5: Metrics on anthropogenic carbon inventory boxes (surfaces and volumes) and the corresponding sequestered carbon in $\mathrm{g} / \mathrm{m}^{3}$ and Teragram of carbon $(\mathrm{Tg} \mathrm{C}$ ) for the TrOCA and the MCM approaches

\begin{tabular}{|c|c|c|c|c|c|c|c|c|c|}
\hline Box & Lat. & Long. & $\begin{array}{c}\text { Volume } \\
\left(\mathrm{m}^{3}\right)\end{array}$ & $\begin{array}{c}\text { Surface } \\
\left(\mathrm{km}^{2}\right)\end{array}$ & $\begin{array}{c}\text { Avr. } \\
\text { Depth }(\mathrm{m})\end{array}$ & 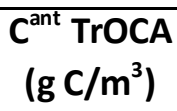 & $\begin{array}{c}C^{\text {ant }} \text { TrOCA } \\
(\operatorname{Tg} C)\end{array}$ & $\begin{array}{l}\mathrm{C}^{\text {ant }} \mathrm{MCM} \\
\left(\mathrm{g} \mathrm{C}^{3} \mathrm{~m}^{3}\right)\end{array}$ & $\begin{array}{c}C^{\text {ant }} M C M \\
(\operatorname{Tg} C)\end{array}$ \\
\hline 1 & 37 & -1 & $5,84 \cdot 10^{13}$ & 30058 & $1812 \pm 997$ & 0.94 & 55.36 & 0.78 & 45.73 \\
\hline 2 & 37 & 1 & $7,12 \cdot 10^{13}$ & 30935 & $2377 \pm 700$ & 0.93 & 65.94 & 0.76 & 54.32 \\
\hline 3 & 37 & 3 & $5,67 \cdot 10^{13}$ & 23865 & $2407 \pm 795$ & 0.94 & 53.56 & 0.78 & 44.29 \\
\hline 4 & 37 & 5 & $5,34 \cdot 10^{13}$ & 22508 & $2425 \pm 735$ & 0.94 & 50.06 & 0.78 & 41.44 \\
\hline 5 & 37 & 7 & $4,42 \cdot 10^{13}$ & 18915 & $2291 \pm 945$ & 0.99 & 43.52 & 0.82 & 36.23 \\
\hline 6 & 37 & 9 & $1,29 \cdot 10^{13}$ & 12840 & $853 \pm 963$ & 0.9 & 11.64 & 0.75 & 9.62 \\
\hline 7 & 39 & 1 & $1,12 \cdot 10^{13}$ & 13830 & $764 \pm 597$ & 0.92 & 10.24 & 0.77 & 8.55 \\
\hline 8 & 39 & 3 & $4,72 \cdot 10^{13}$ & 26018 & $1743 \pm 991$ & 0.94 & 44.36 & 0.78 & 36.63 \\
\hline 9 & 39 & 5 & $9,06 \cdot 10^{13}$ & 37527 & $2535 \pm 585$ & 0.94 & $8 \overline{5.46}$ & 0.78 & 70.60 \\
\hline 10 & 39 & 7 & $9,48 \cdot 10^{13}$ & 38393 & $2618 \pm 585$ & 0.94 & 88.8 & 0.78 & 73.6 \\
\hline 11 & 39 & 9 & $2,42 \cdot 10^{13}$ & 21751 & $1014 \pm 820$ & 0.9 & 21.88 & 0.75 & 18.28 \\
\hline
\end{tabular}


Table 6: Comparison of anthropogenic carbon inventory in different marginal seas (Pg C: Petagram of Carbon)

\begin{tabular}{|c|c|c|c|c|c|}
\hline $\begin{array}{l}\text { Marginal } \\
\text { Seas }\end{array}$ & Year & $\begin{array}{c}\mathrm{C}^{\text {ant }} \text { inventory } \\
(\mathrm{Pg} \mathrm{C})\end{array}$ & $\begin{array}{c}\text { Surface } \\
\left(\times 10^{6}\right. \\
\left.\mathrm{km}^{2}\right) \\
\end{array}$ & Calculation method & Reference \\
\hline \multirow{2}{*}{$\begin{array}{l}\text { Mediterranean } \\
\text { Sea }\end{array}$} & 2001 & $1.7 \pm 0.4$ & \multirow{2}{*}{2.5} & TTD & (Schneider et al., 2010) \\
\hline & 2001 & 1 & & Regional Model & (Palmiéri et al., 2015) \\
\hline Algerian Basin & 2014 & $0.44-0.53 \pm 0.06$ & 0.28 & $\begin{array}{c}\text { Chen and Millero (1979) and } \\
\text { TrOCA }\end{array}$ & Current study \\
\hline Bering Sea & 1980 & $0.21 \pm 0.05$ & 1.1 & Chen and Millero (1979) & (Chen, 1993) \\
\hline Okhotsk Sea & 1998 & $0.18 \pm 0.08$ & 1.01 & Chen and M1 . ro (1979) & $\begin{array}{c}\text { (Chen and Tsunogai, } \\
\text { 1998) }\end{array}$ \\
\hline \multirow[b]{2}{*}{ Japan Sea } & 1992 & $0.31 \pm 0.05$ & \multirow[b]{2}{*}{0.74} & Chen and Milles) (1979) & (Chen et al., 1995) \\
\hline & 1999 & $0.40 \pm 0.06$ & & $\begin{array}{l}\text { Traces bast } 1 \text { technique } \\
\text { (c.'orofluorocarbon) }\end{array}$ & (Park et al., 2006) \\
\hline $\begin{array}{l}\text { East China and } \\
\text { Yellow Seas } \\
\end{array}$ & 1992 & $0.07 \pm 0.02$ & 0.9 & hen ind Millero (1979) & (Chen et al., 2004) \\
\hline South China Sea & 1999 & $0.6 \pm 0.15$ & 1.1 & Chen and Millero (1979) & (Chen et al., 2006b) \\
\hline Sulu Sea & 1996 & 0.28 & 0.35 & Chen and Millero (1979) & (Chen et al., 2006a) \\
\hline \multirow{3}{*}{$\begin{array}{l}\text { Nordic Seas } \\
\text { (Norwegian and } \\
\text { Greenland Seas) }\end{array}$} & 1990 & 0.85 & \multirow{3}{*}{$\sim 2.6$} & Chen and Millero (1979) & (Chen et al., 1990) \\
\hline & 2002 & 1.2 & & $\begin{array}{l}\text { Method combining nutrients } \\
\text { and CFC data }\end{array}$ & (Jutterström et al., 2008) \\
\hline & 2002 & $0.9-1.4$ & & TTD & (Olsen et al., 2010) \\
\hline
\end{tabular}


Table 7: The Mean variation of $\mathrm{pH}$ and seawater saturation states in regards to calcite $\left(\Delta \Omega_{\mathrm{Ca}}\right)$ and aragonite $\left(\Delta \Omega_{\mathrm{Ar}}\right)$, between the preindustrial era and the summer of 2014. The table shows the results considering the anthropogenic carbon computed by both the TrOCA and the MCM approaches.

\begin{tabular}{|c|c|c|c|c|}
\hline Parameter & Min. & Mean value & Max. & SD \\
\hline$\overline{\Delta \Delta \mathrm{pH}_{\mathrm{MCM}}}$ & -0.19 & -0.115 & 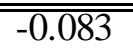 & \pm 0.008 \\
\hline$\Delta \mathrm{pH}_{\mathrm{TrOCA}}$ & -0.199 & -0.134 & -0.101 & \pm 0.007 \\
\hline$\Omega_{\mathrm{Ca}} 2014$ & $\overline{2.414}$ & 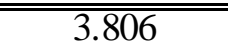 & 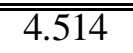 & \pm 0.501 \\
\hline$\Omega_{\mathrm{Ar}} 2014$ & 1.603 & 2.464 & 2.909 & \pm 0.306 \\
\hline$\Omega_{\mathrm{Ca}}$ preind (MCM) & 3.143 & 4.712 & 5.764 & \pm 0.644 \\
\hline$\Delta \Omega_{\mathrm{Ca}}($ Chen $)$ & -1.564 & -0.907 & -0.567 & \pm 0.156 \\
\hline$\Omega_{\mathrm{Ca}}$ preind (TrOCA) & 3.307 & 4.868 & 5.816 & \pm 0.639 \\
\hline$\Delta \Omega_{\mathrm{Ca}}(\operatorname{TrOCA})$ & -1.644 & -1.063 & -0.722 & \pm 0.149 \\
\hline$\Omega_{\mathrm{Ar}}$ preind $(\mathrm{MCM})$ & 2.087 & 3.051 & 3.718 & \pm 0.394 \\
\hline$\Delta \Omega_{\mathrm{Ar}}(\mathrm{MCM})$ & -1.008 & -0.587 & -0.376 & \pm 0.097 \\
\hline$\Omega_{\mathrm{Ar}}$ preind (TrOCA) & 2.197 & $\overline{1} \overline{1} \overline{2}$ & 3.747 & \pm 0.39 \\
\hline$\Delta \Omega_{\mathrm{Ar}}(\operatorname{TrOCA})$ & -1.06 & $-66 \overline{c 8}$ & -0.479 & \pm 0.091 \\
\hline \multicolumn{5}{|c|}{$\overline{\text { Pre vious studies (Medite }} \overline{\overline{-}} \overline{\bar{c} \text { ean Sea) }}$} \\
\hline$\Delta p H_{2001}^{T r O C A}$ (Touratier and Goyet, 2011) & -0.05 & - & 0.14 & - \\
\hline$\Delta p H_{2001}^{\text {Model }}$ (Palmiéri et al., 2015) & $-0,06$ & - & $-0,005$ & - \\
\hline$\Delta p H_{2008}^{T r O C A}$ (Touratier et al., 2012) & $-r,: 78$ & - & $-0,061$ & - \\
\hline$\Delta p H_{2013}^{T r O C A}$ (Hassoun et al., 2015a) & $\bar{n} 56$ & - & -0.055 & - \\
\hline
\end{tabular}

SD: Sundard deviation; $\mathrm{N}=618$ : number of considered data 


\section{Highlights:}

- The first high resolution spatial coverage of the Algerian Basin allowed a detailed study of the carbonate system parameters using a new dataset (SOMBA 2014: Système d'Observations à la mer dans le Bassin Algérien).

- A refitted back-calculation method of anthropogenic carbon that considers the characteristics of the Mediterranean Sea displays similar results to the well-known TrOCA method.

- Highlighting of the role of the neglected submesoscan processes, correlated with mesoscale activity, in the increase of anthropogenic cr bor sequestration.

- The estimated acidification of the Algerian Basu from the preindustrial era to 2014 range between -0.19 and $-0.1 \mathrm{pH}$ unit.

- The first estimate of the anthropoget ic curbon inventory trapped by the Algerian Basin using in situ data is about 0 +4- $0.5 \pm \pm 0.06 \mathrm{Pg} \mathrm{C}$ in 2014. 


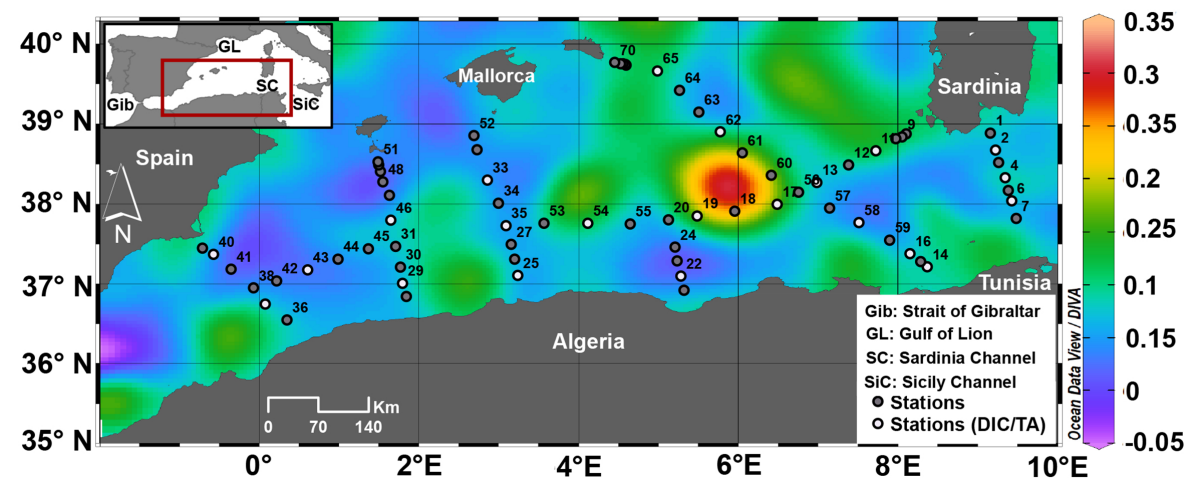

Figure 1 
(a) TA Residuals $(\mu \mathrm{mol} / \mathrm{kg})$

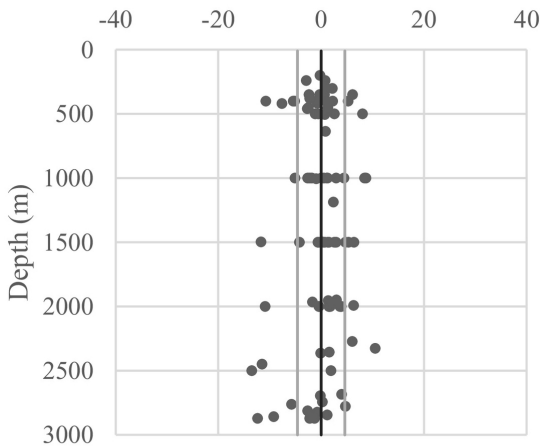

- Residuals

- $\mathrm{SDr}=4.6 \mu \mathrm{mol} / \mathrm{kg}$

— Mean residuals $=0 \mu \mathrm{mol} / \mathrm{kg}$ (b)

DIC Residuals ( $\mu \mathrm{mol} / \mathrm{kg})$

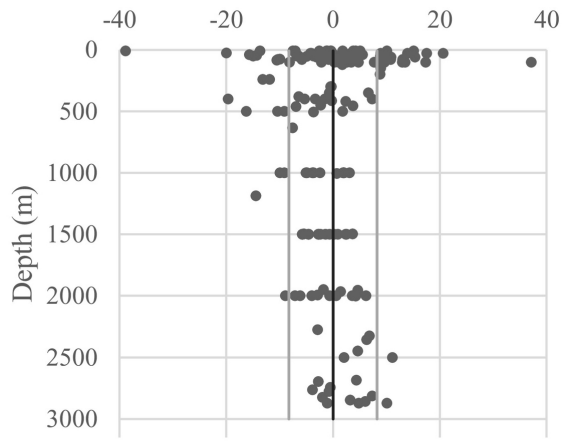

- Residuals

$\mathrm{SDr}=8.28 \mu \mathrm{mol} / \mathrm{kg}$

- Mean residuals $=0 \mu \mathrm{mol} / \mathrm{kg}$

Figure 2 


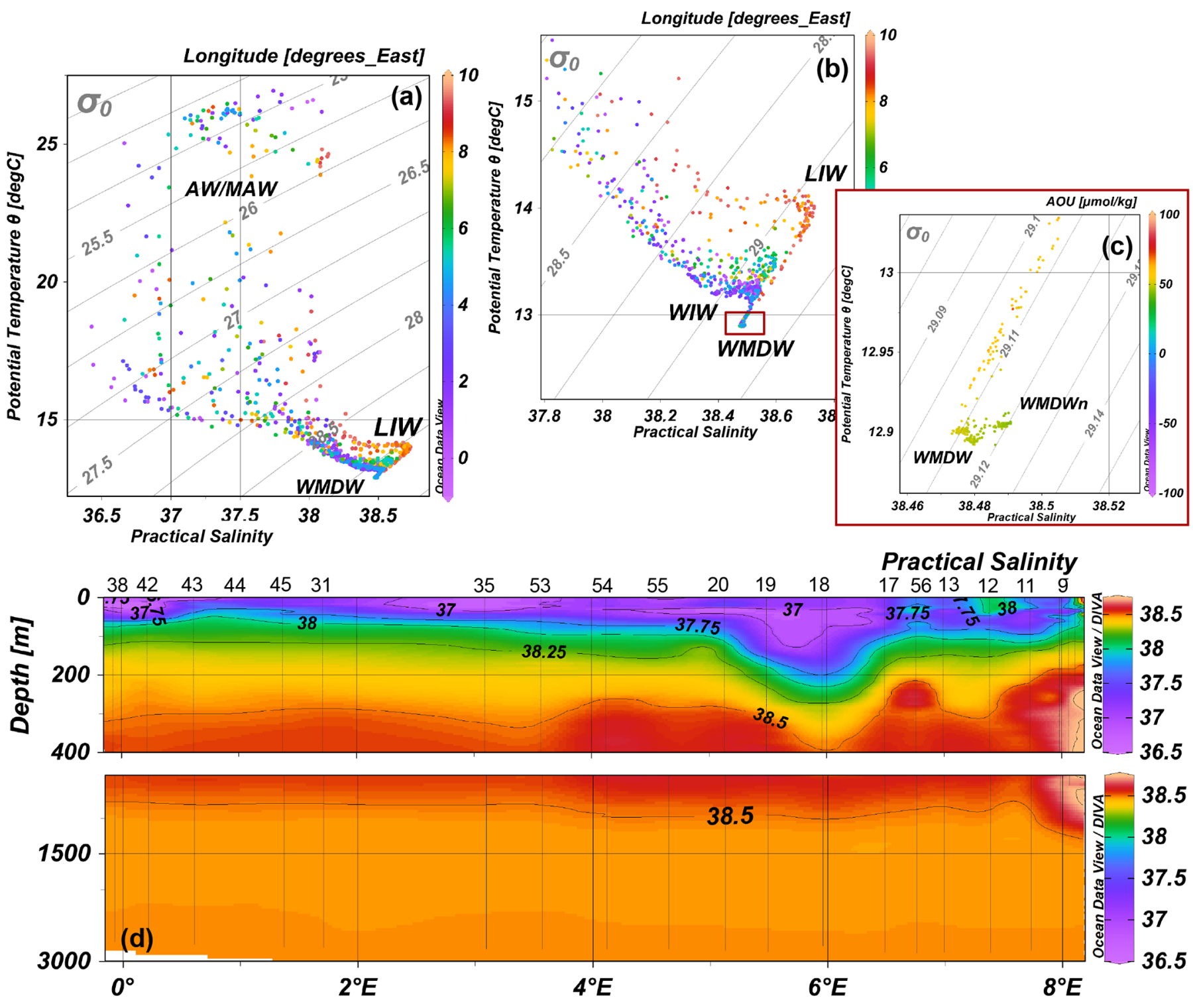

Figure 3 

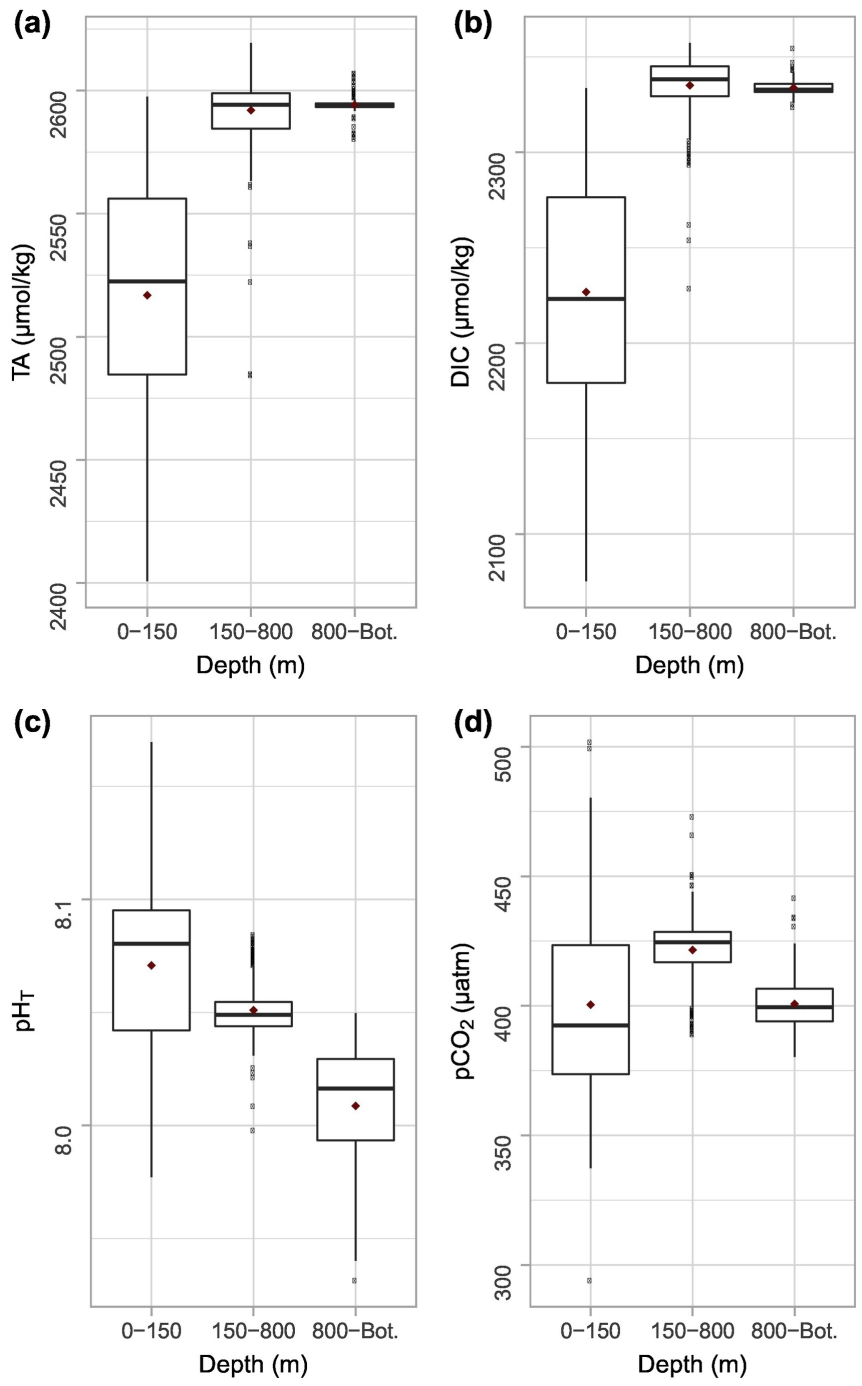

Figure 4 


\section{TA ( $\mu \mathrm{mol} / \mathrm{kg})$}

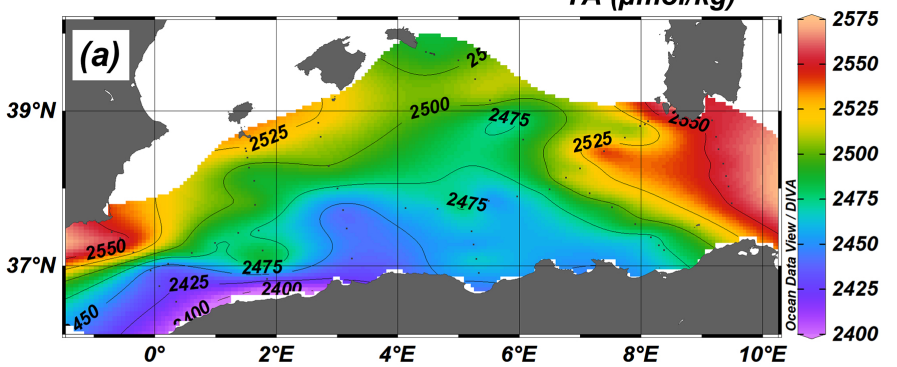

\section{DIC $(\mu \mathrm{mol} / \mathrm{kg})$}
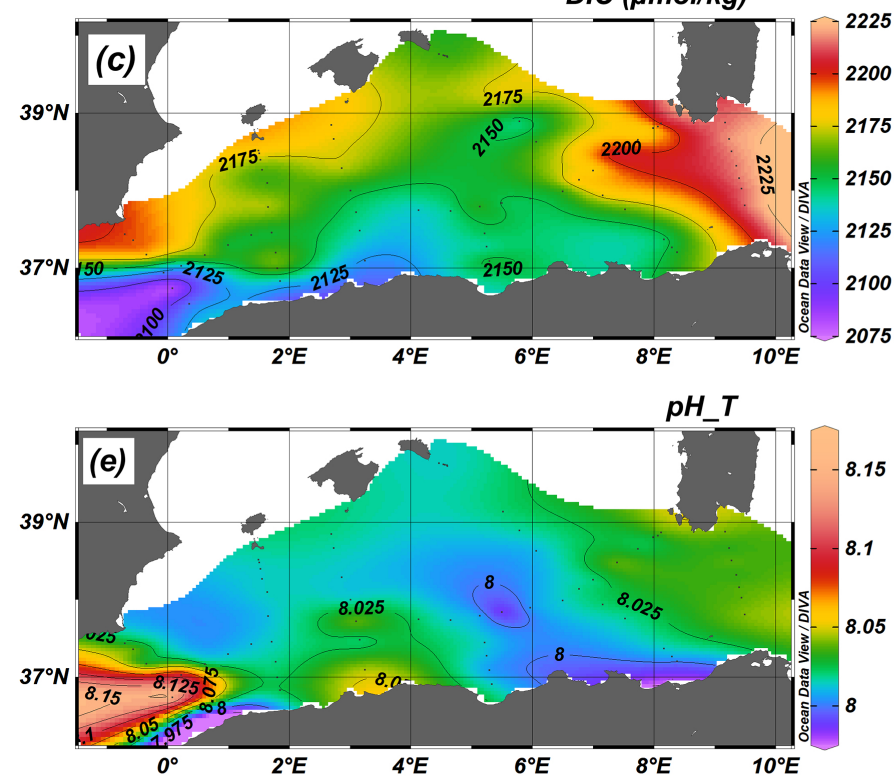

Oxygen saturation (\%)

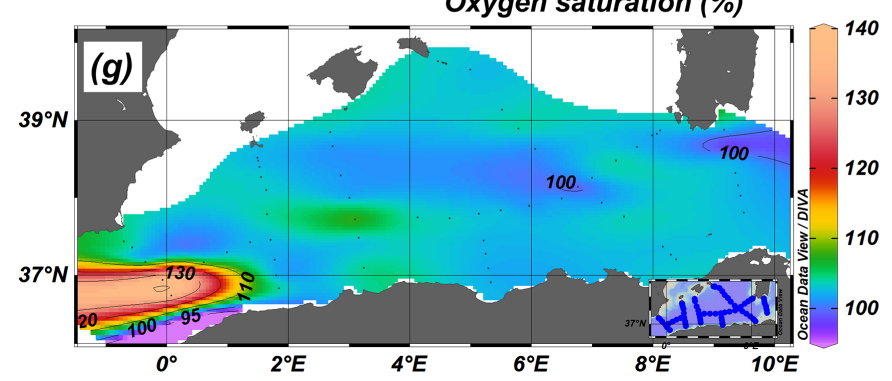

NTA $(\mu \mathrm{mol} / \mathrm{kg})$

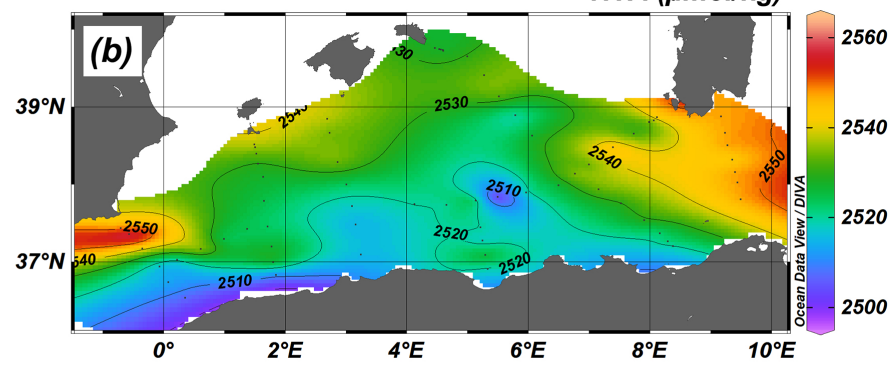

NDIC ( $\mu \mathrm{mol} / \mathrm{kg})$
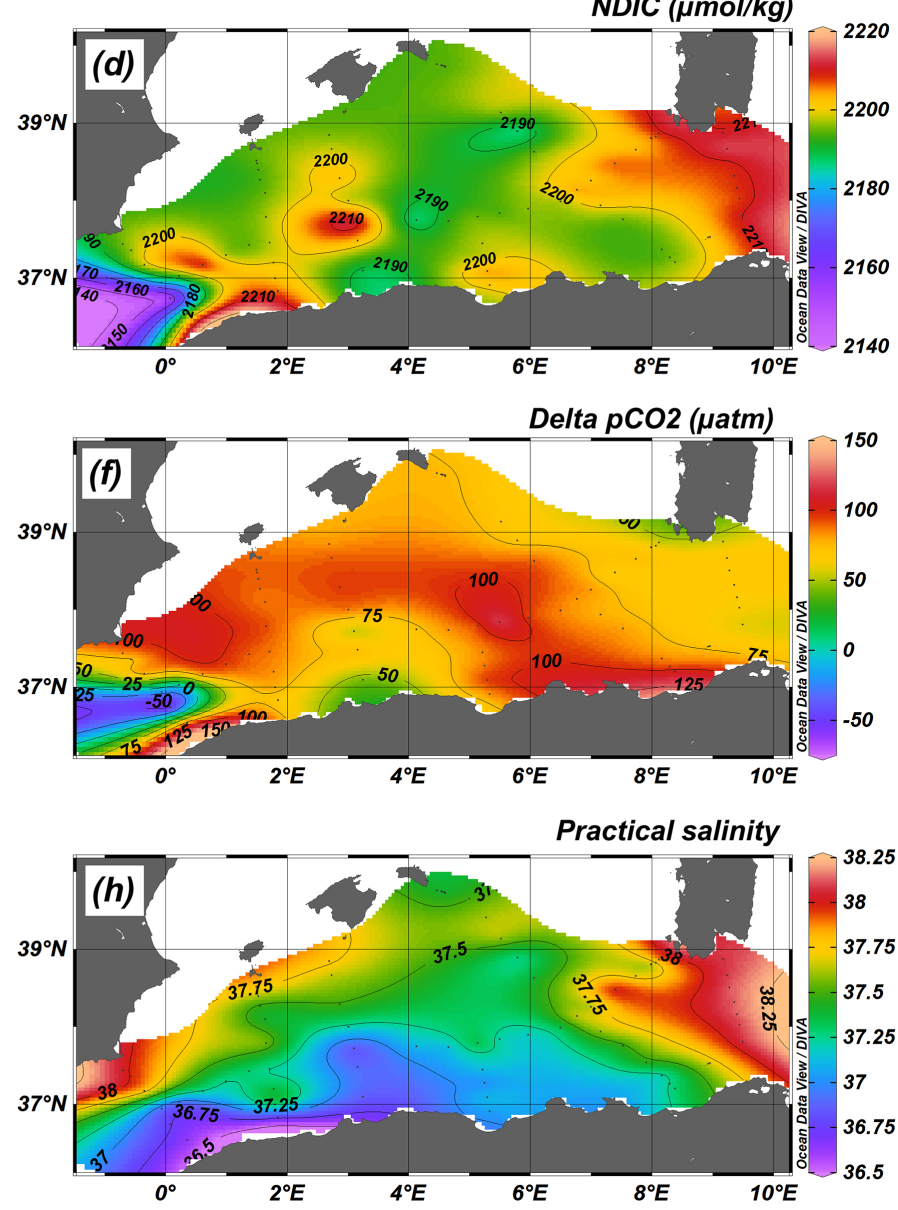

Figure 5 
$T A[\mu \mathrm{mol} / \mathrm{kg}]$

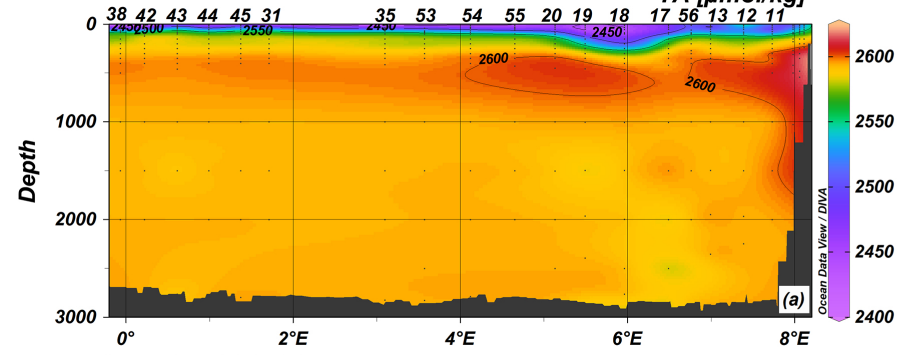

lix

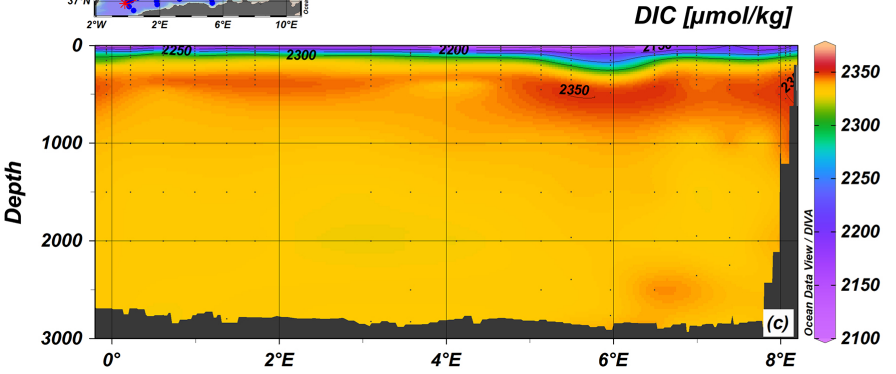

NTA [umol/ $\mathrm{kg}]$
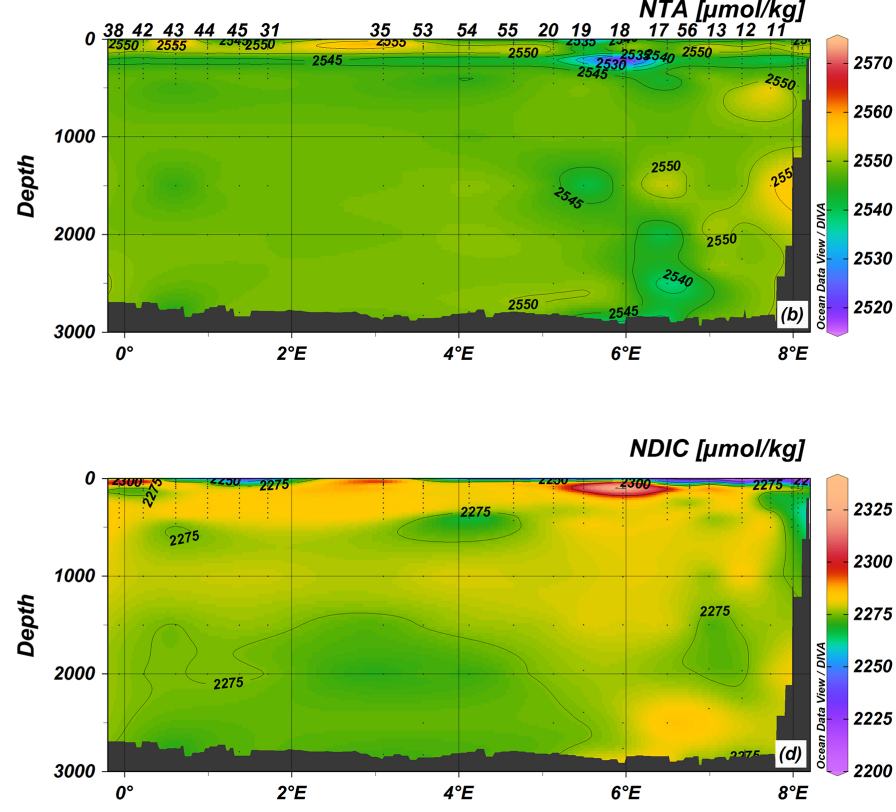

Figure 6 

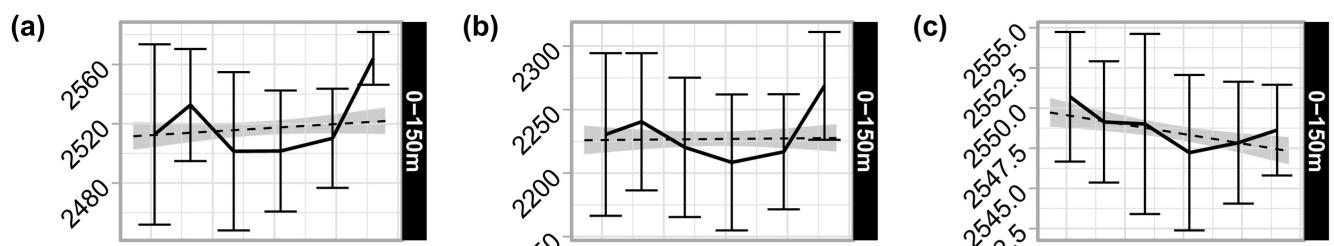

(d)
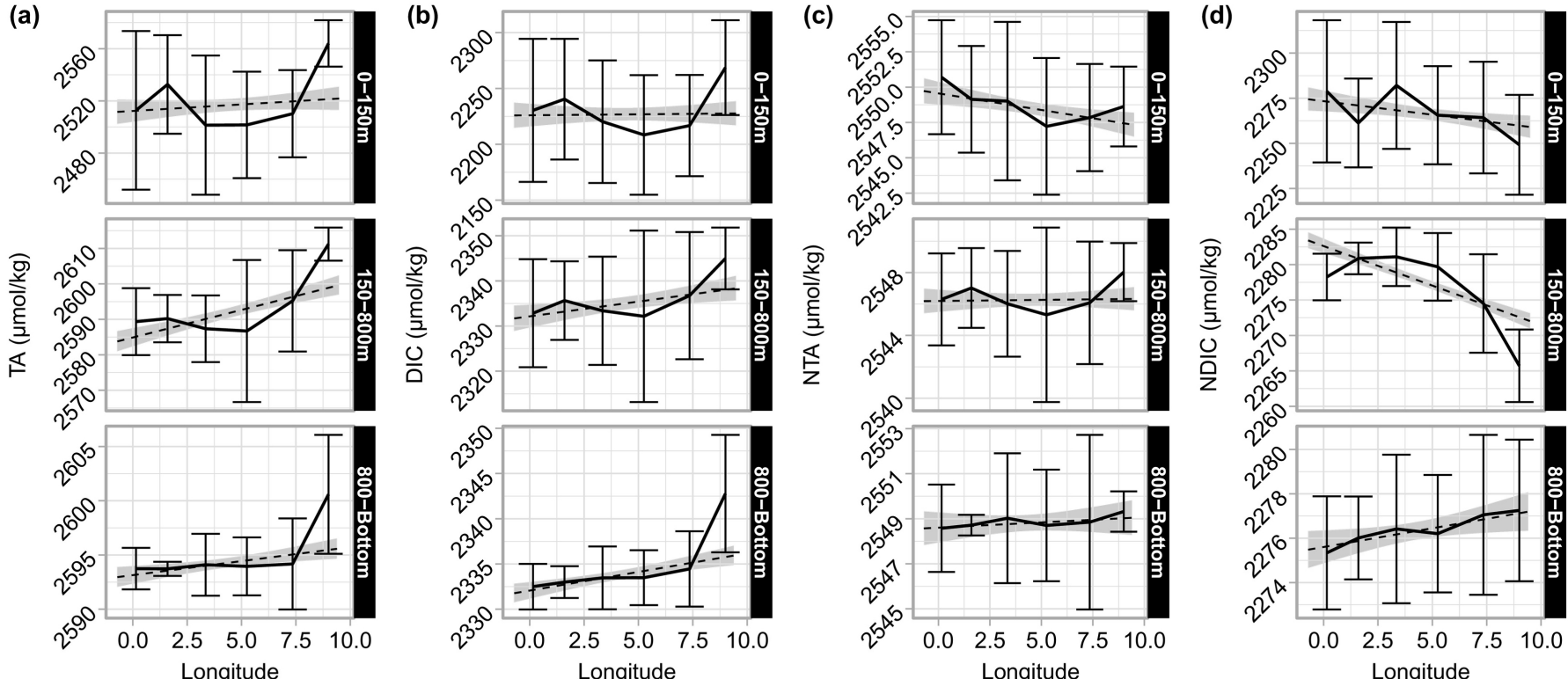

(e)

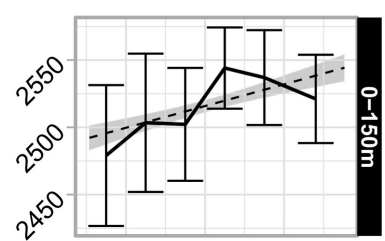

(f)

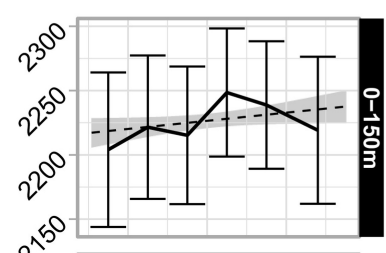

(g)
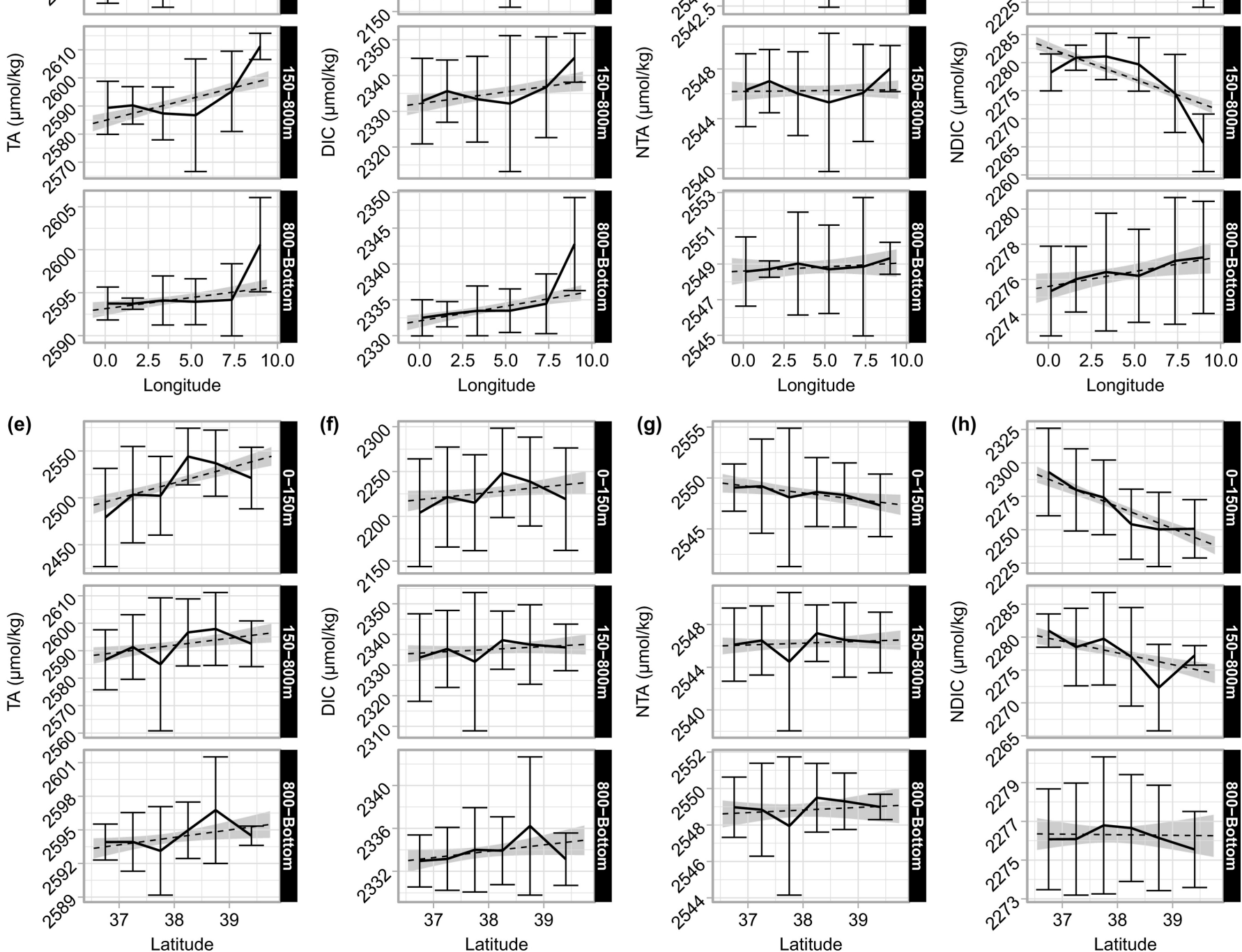

(h)
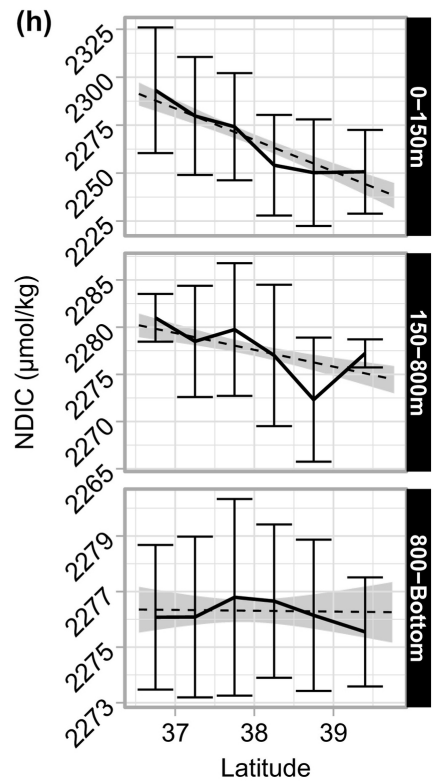

Figure 7 


\section{Cant MCM [ [ $\mathrm{mol} / \mathrm{kg}]$}

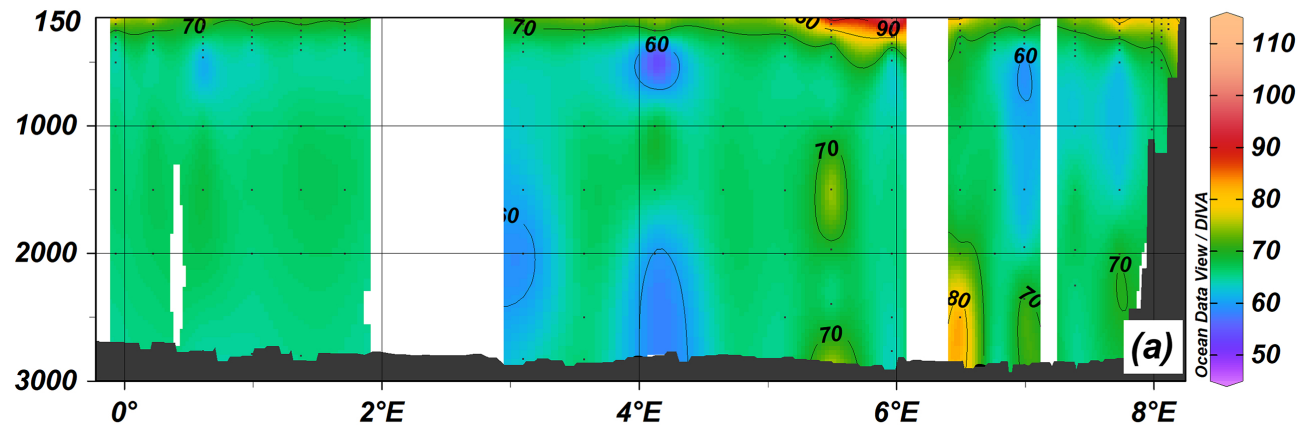

Cant TrOCA [ $\mu \mathrm{mol} / \mathrm{kg}]$
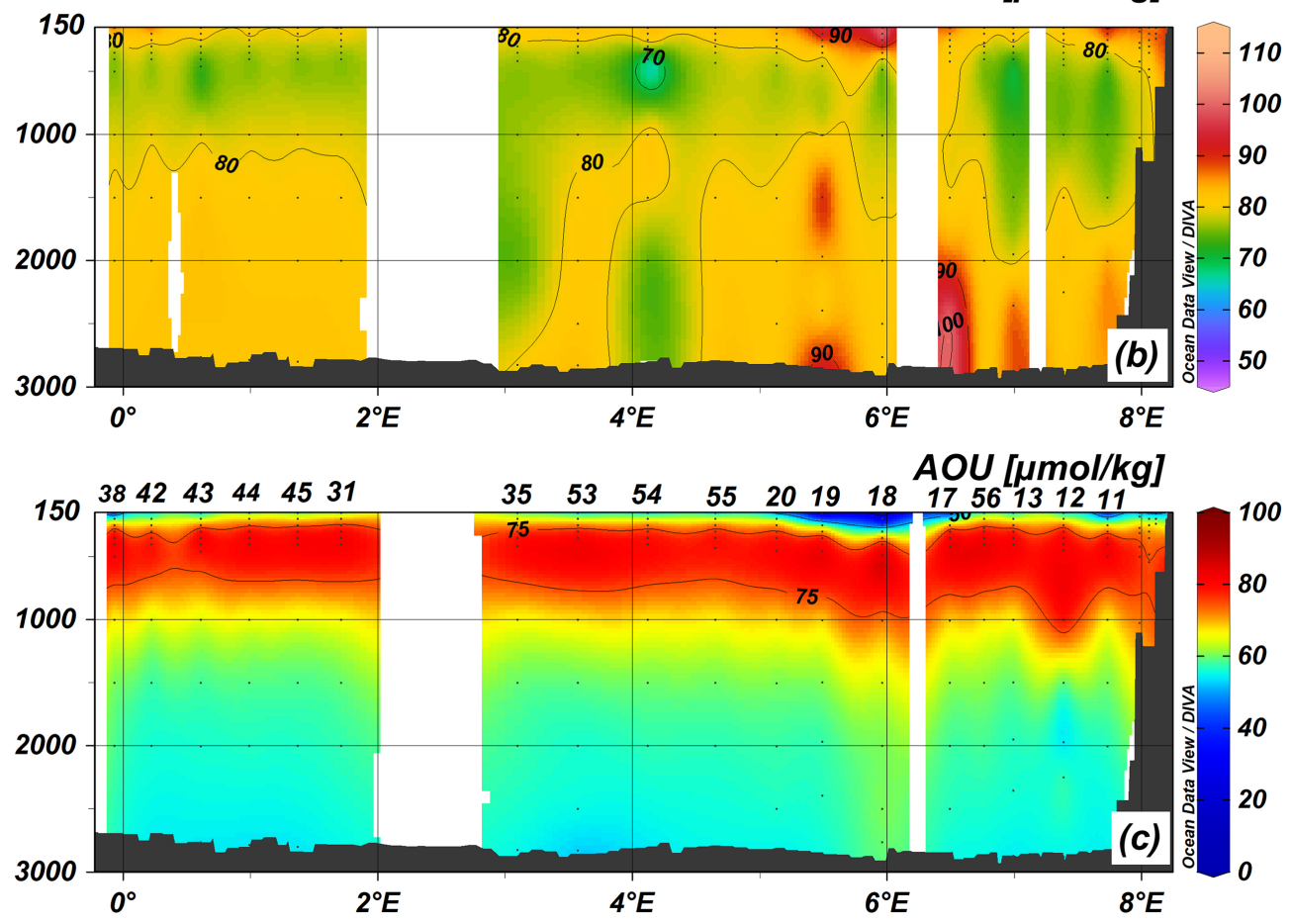

Figure 8 


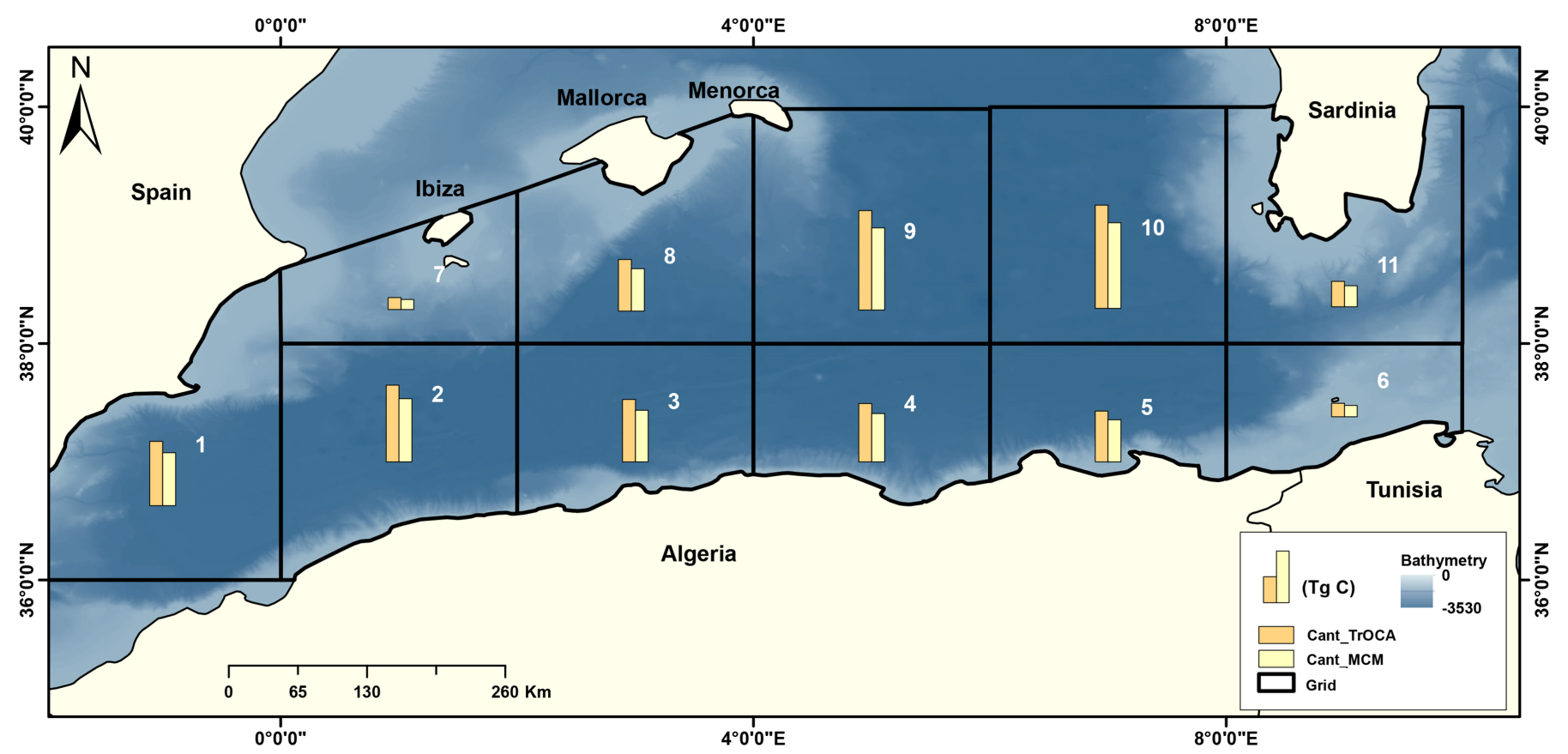

Figure 9 
Delta pH_MCM

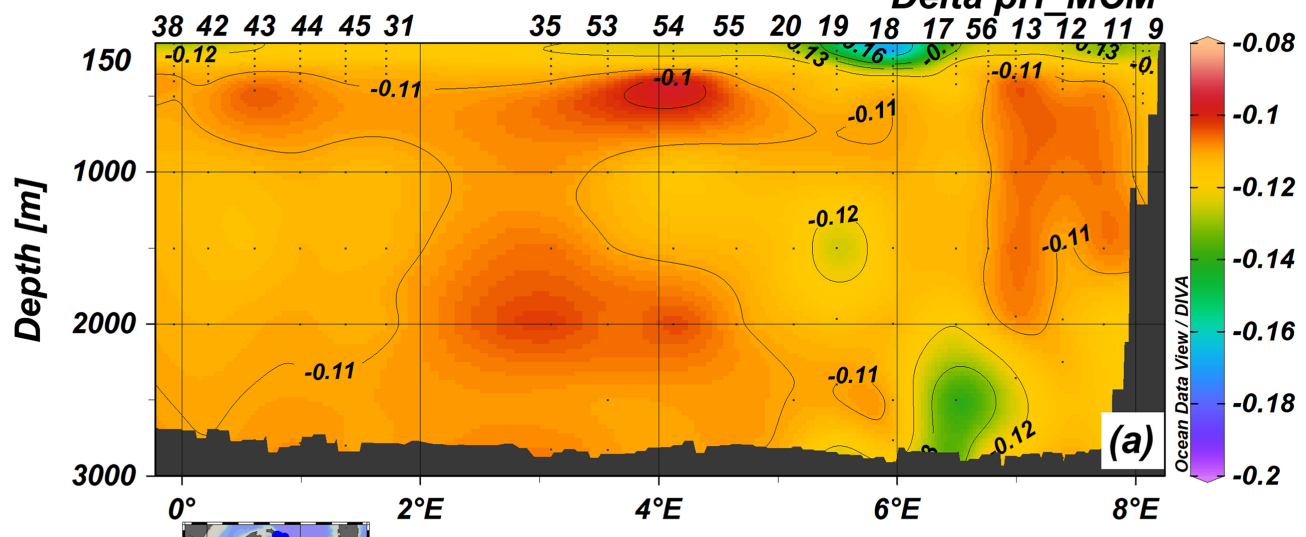

\section{Delta pH_TrOCA}

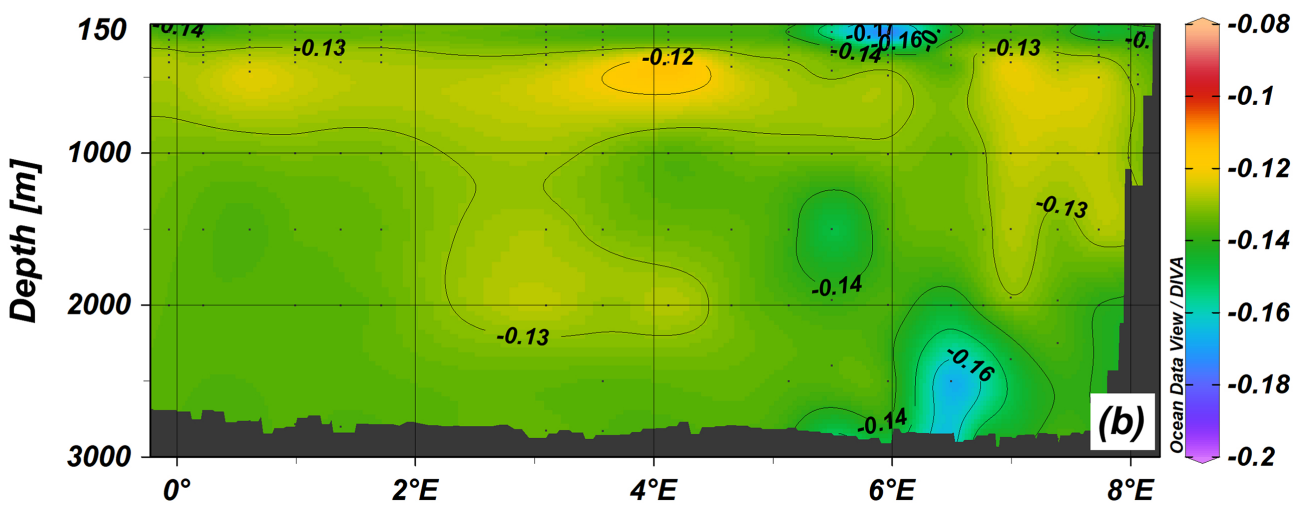

Figure 10 